\title{
Estimation of spatially distributed groundwater potential recharge for the United Kingdom.
}

(1)

\author{
M. M. Mansour ${ }^{1 *}$, L. Wang ${ }^{1}$, Mark Whiteman ${ }^{2}$, \& A. G. Hughes ${ }^{1}$
}

${ }^{1}$ British Geological Survey, Environmental Science Centre, Nicker Hill, Keyworth, Nottingham NG12 $5 G G$, UK

${ }^{2}$ Environment Agency, Coverdale House, Aviator Court, Amy Johnson Way, Clifton Moor, York, YO30 $4 \mathrm{GZ}, \mathrm{UK}$

*Corresponding author (e-mail: majm@bgs.ac.uk)

\begin{abstract}
The calculation of distributed recharge is necessary to drive numerical groundwater models used to manage and protect groundwater resources, to assess the impact of anthropogenic stresses and climate change, and to study the viability of technologies, such as exploiting the heat stored in the ground. A national scale model allows policy-makers and governmental decision-makers to set policy within the correct geographical context. However, many challenges are associated with building large scale models, for example, the representation of processes on coarse grid resolution. This study presents distributed potential recharge values, calculated using the modified EA/FAO recharge algorithm. The model calibration is presented and the simulated potential recharge values and soil moisture deficit values are compared with estimates provided by the Environment Agency and the Meteorological Office. Long-term average potential recharge values are very small in the east of the UK but they increase significantly towards the west and north reaching values as high as $8 \mathrm{~mm}$ day $^{-1}$ over the hills of Wales and Scotland. While this study highlights the need for further model refinement, the presented results are useful for assessing the potential recharge values at a national scale and for undertaking water resources studies especially in catchments with unconfined/nearsurface aquifers.
\end{abstract}

\section{Introduction}

Methods of calculating recharge are necessary to effectively manage groundwater resources. Groundwater systems are vulnerable to potential increased abstraction in future and to climate variabilities mainly due to changes in temperature and precipitation (Holman et al., 2009). A need to understand, quantify and predict groundwater flow in aquifers has meant that models have been developed to address these issues. The use of numerical models for the testing of conceptual models and subsequently for water resources management started in the 1970s in the UK; however, since the 1990s, the Environment Agency has established a large programme to develop conceptual and numerical models of the principal aquifers of England and Wales and their associated superficial deposits (Shepley et al., 2012). Since groundwater flows are mainly driven by water infiltration through the soil down to the groundwater table, the quantification of the resulting aquifer recharge is essential, therefore, to drive these numerical models.

Policy-makers and governmental decision-makers often pose questions at a national scale, as they have to set policy for this geographical extent. For example, the assessment of Nitrate Sensitive Areas to determine the impact of nitrate concentrations on groundwater at a national scale (e.g. Silgram et al., 2005; Wang et al., 2016; Wang et al., 2017). Over the last decade, the impact of 
climate change has become increasingly important to decision-makers and has fed through into their questions for future resource management. The abstraction reform process led by UK's Defra (Department for Environment Farming and Rural Affairs) has meant that the water balance at a national scale is important and that the interaction between climate change and land use / land cover change required examination (Mansour and Hughes, 2014). The UK's implementation of the EU Water Framework Directive requires water balances for groundwater units to be undertaken as well as the UK government need for the implications of climate change on recharge volumes to be assessed. The latter requires a nationally consistent approach, which requires a UK-scale recharge model. An additional example of the requirements for national scale models is the estimation of recharge volumes and soil moisture content to inform the design, construction, and efficiency of electrical earthing under future climate (Busby et al., 2012). To address these questions and support government-level work, a national scale recharge model has been built for the UK and is presented in this paper.

Many factors influence the calculation of recharge including the amount, duration and intensity of precipitation, evaporation and consequently evapotranspiration, topography, soil types, bedrock geology, antecedent soil moisture conditions, and anthropogenic impact such as irrigation, leakages from sewers, surface pavements, etc. Several recharge studies have been undertaken on a regional, national, and global scale by applying different techniques. In the UK, the Humberbank study (University of Birmingham, 1978; Hutchinson et al., 2012) used Soil Moisture Deficit (SMD) recharge models based on the work by Penman and Grindley (Lerner et al, 1990; Rushton and Ward 1979) in conjunction with groundwater flow models. In this study, the recharge was calculated at a single location and then spatially distributed using a factor derived from a subjective analysis of a combination of rainfall, elevation and land use. This approach was extended and used for a number of other regional investigations related to the main aquifers in the UK, including the Chalk (e.g. Cross et al, 1995), the Triassic Sandstone (e.g. Rushton et al., 1995) and the Lincolnshire Limestone (e.g. Bradbury and Rushton, 1998) groundwater systems.

To support the Environment Agency's groundwater modelling programme, recharge methodologies were developed and their encapsulation in recharge models was undertaken (Quinn et al., 2012). Heathcote et al. (2004) benchmark such a model against recharge calculations for the Lincolnshire Limestone (Bradbury and Rushton, 1998) and present results for the West Midlands Worfe model. They use the Food and Agriculture Organization (FAO) method (Hulme et al., 2001) combined with runoff routing to calculate distributed potential recharge.

On a national scale, Hunter Williams et al. (2013) use hydrogeological datasets incorporated in a geographic information system (GIS) and the results of groundwater recharge studies to produce a national map of groundwater recharge coefficients and annual average groundwater recharge for Ireland. They calculate effective precipitation and then factor it based on the hydrogeological setting to produce actual recharge.

On a global scale, the $0.5^{\circ}$ by $0.5^{\circ}$ WaterGAP Global Hydrology Model (WGHM) was used by Döll and Fiedler (2008) to estimate recharge over Europe. It uses the GTOPO30 Digital Elevation Model, the Global Land Cover Characterisation (GLCC) map, the FAO soil map, Lakes, Wetlands, the river discharge data, and weather data. However, this model also includes many coefficients and parameters that are determined or specified based on a subjective or expert judgement basis.

As the scale of the model application increases, so inevitably the physics represented in the model may become simplified. Other workers have addressed this by developing more sophisticated recharge calculation approaches and applying them at a smaller scale studies. Of particular interest 
is the four root layer model (FRLM) developed at the Institute of Hydrology, now CEH Wallingford (Finch, 2001; Ragab et al., 1997), in which the soil layer was split into four horizons and allows water to move vertically when the uppermost soil store is full. The model has been applied to undertake point calculations in the UK (Ragab et al., 1997) and for catchment based recharge assessments (Finch, 2001 and Bradford et al., 2002). Holman et al. (2011) deploy a "meta-model" approach they apply to assess the recharge for England and Wales. They use a one-dimensional soil water balance model WaSim (Hess et al., 2000) to understand the effects of soil quality on recharge expressed as baseflow.

The UK recharge calculations presented in this paper are obtained using a similar approach to the above studies, where GIS layers describing different hydrological processes are implemented within the recharge calculation method to improve the quality of the assessment of recharge values. The major difference in the approach presented in this study is the possibility of calibrating the model by comparing the simulated hydrological processes such as the overland flows and the soil moisture deficit to the observed processes.

The aim of this paper is to present the methodology followed to create the national potential recharge map of the UK. The recharge calculation method together with the other hydrological processes accounted for in this methodology are firstly presented. This is followed by a description of the calibration process and the benchmarking of the recharge values by comparing them to those calculated in previous studies. The benchmarking exercise aims to assess where the methodology works and to identify deficiencies for future improvements. This paper does not aim to publish the estimated potential recharge values; rather, these must be interpreted within the context of the recharge modelling being undertaken and accounting for the simplifications associated with the applied methodology.

\section{The study area}

The area modelled in this study is defined by the coastlines of England, Wales and Scotland including the major islands that are close to the coastline (e.g. Isle of Wight, Anglesey and the Inner Hebrides) (Figure 1). The total modelled area is approximately $234,000 \mathrm{~km}^{2}$. The UK landscape is varied. Scotland to the north and Wales to the west are mountainous, with peaks reaching maximum elevations of $1300 \mathrm{~m}$ and $1000 \mathrm{~m}$ above sea level in Scotland (Grampian Mountains including Ben Nevis) and Wales (Snowdonia including Snowden) respectively. In northern England (Eden catchment), there are the Cumbrian Mountains in the west and the Pennines in the east and other moorlands in the south reaching elevations of $900 \mathrm{~m}$ above sea level. Most of the rest of England consists of gently rolling hills with isolated areas of high ground and low lying coastal areas, especially in the east and south of England.

The climate varies across the UK with England having higher temperatures and Scotland being cooler than the rest of the UK (Met Office, www.metoffice,gov.uk). Table 1 shows a summary of highest and lowest temperatures as well as the average rainfall in England, Scotland, and Wales.

Land use is predominantly agricultural, occupying about $70 \%$ of the UK landmass (approximately $19 \%$ crops and bare fallow, $52 \%$ grasses and rough grazing). Forest and woodland covers approximately $12 \%$ of the land area, and the remaining $18 \%$ of the land is covered with other features such as residential and commercial developments, transport related infrastructure and land for recreational use (Bibby, 2009). 


\section{Description of the model code}

131 This study uses the Zooming Object Oriented Distributed Recharge Model (ZOODRM) (Mansour and 132 Hughes, 2004, Hughes et al., 2008, Mansour et al., 2011) to estimate potential recharge over the UK.

133 Groundwater recharge is called diffuse or direct recharge when the infiltrated water derives from precipitation or irrigation that occurs uniformly over large areas. It is called localized or indirect recharge when infiltrating water originates from features such as streams and lakes (Scanlon et al., 2002). In both cases, groundwater recharge is the water that reaches the saturated part of the porous medium or the water table. Unsaturated processes can divert water infiltrating into the subsurface, preventing it from reaching the saturated zone. The presence of low permeability materials, or aquicludes, for example, may stop the vertical movement of water within the unsaturated zone creating perched saturated zones or forcing the water to move to other features such as rivers, lakes, or springs. Because this study does not account for these processes, the term potential recharge is used rather than recharge. Potential recharge, as defined by Rushton (1997), is the water that has infiltrated but that may not necessarily reach the water table because of unsaturated-zone processes or the ability of the saturated zone to accept recharge.

ZOODRM permits the incorporation of multiple grids at difference scales (Mansour and Hughes, 2004). For example, the model uses a relatively coarse grid to incorporate the regional characteristics of the study area within the model and introduces grid refinement over the areas where groundwater flows need to be simulated in greater detail. The model calculates potential recharge values at each of the grid nodes using a daily time step and according to a recharge calculation algorithm selected based on climatic characteristics of the study area. For example, recharge calculations in temperate areas can be performed using either the soil moisture deficit method (SMD) based on the work of Penman (1948) and Grindley (1967), the Environment AgencyFAO (EA-FAO) method (Hulme et al., 2002), or the modified FAO method (Griffiths et al., 2006). The recharge model is developed using the object-oriented modelling approach, which permits the addition of any new recharge calculation algorithm into the model. Other recharge calculation methods that were implemented in the model and applied to semi-arid areas can be found in the work of Hughes et al. (2008) and Ò Dochartaigh et al. (2010).

The Environment Agency of England and Wales (now the Environment Agency of England) developed a recharge calculation method that incorporates a representation of seasonal plant growth including drilling, emergence, senescence, and harvesting (Hulme et al, 2002). The method is based on the estimation of crop water requirements reported in the FAO Drainage and Irrigation Paper 56 (FAO, 1998). This method calculates the capacity of the soil zone, represented by two parameters, the Readily Available Water (RAW) and Total Available Water (TAW), and from which plants draw water to evapo-transpire. These parameters are calculated using plant characteristics, e.g. the root depth and the depletion factor, and soil characteristics, e.g. the moisture content at field capacity and wilting point. Evapo-transpiration is then calculated as a function of the values of soil moisture deficit, RAW, and TAW. required to apply the method has been reduced. However, the general principles of the original FAO method have been maintained. For example, the total available water (TAW) and the readily available water (RAW) that a plant can evapo-transpire are calculated using the same equations used 
where $Z_{r}[\mathrm{~L}]$ and $p[-]$ are the root depth and depletion factor of a plant respectively, $\theta_{f c}\left[\mathrm{~L}^{3} \mathrm{~L}^{-3}\right]$ and $\theta_{w p}\left[\mathrm{~L}^{3} \mathrm{~L}^{-3}\right]$ are the moisture content at field capacity and wilting point respectively.

177 Griffiths et al. (2006) calculates the evapo-transpiration rates as a function of the potential evaporation and an intermediate soil moisture deficit

$$
\begin{array}{ll}
\quad e_{s}=e_{p}\left[\frac{s_{s}^{*}}{T A W-R A W}\right]^{0.2} & S_{s}^{*}<R A W \\
e_{s}=e_{p} & S_{s}^{*} \geq R A W \\
e_{s}=0 & S_{s}^{*} \leq T A W
\end{array}
$$

where $e_{s}[\mathrm{~L}]$ is the evapo-transpiration rate, $e_{p}[\mathrm{~L}]$ is the potential evaporation rate and $s_{s}^{*}[\mathrm{~L}]$ is the intermediate soil moisture deficit given by

where $r[\mathrm{~L}]$ is the rainfall and $s_{s}^{t-1}[\mathrm{~L}]$ is the soil moisture deficit calculated at the previous time step.

The new soil moisture deficit is then calculated from:

Griffiths et al. (2006) proposed that recharge and overland flow is only generated when the calculated soil moisture deficit becomes zero. The remaining volume of water, the excess water, is then split into recharge and overland flow using a runoff coefficient. While this runoff coefficient is set to a constant at a node, the amount of runoff and recharge generated at every time step depends on the calculated excess water, which is controlled by the intensity of rainfall and the soil moisture deficit. This study uses the modified EA-FAO method proposed by Griffiths et al. (2006).

Overland flow is simulated at every grid node as a percentage of excess water calculated when the soil moisture deficit is satisfied and reaches a value of zero at this node. This percentage value, the runoff coefficient, has to be specified at every grid node. In addition to rainfall intensity, overland flows depend on other factors such as the steepness of the gradient of the ground surface and the soil texture. Overland flow is routed downstream to the nearest water feature using an aspect direction map that is derived from a topographical map in a GIS environment.

The model can control the speed and volumes of overland flows and river flows by applying the Manning equation using a specified roughness coefficient and the slope of the ground surface as obtained from the digital terrain model. This process has not been applied in this study because the daily time step used to undertake the recharge simulation is too large to represent these detailed surface flow processes accurately. Land use classifications are implemented such that each grid node can have more than one landuse class allocated to it. The model calculates actual evapotranspiration and recharge values at a grid node by applying the recharge method for every specified landuse class and scaling it according to the percentage distribution of landuse present at the grid node.

The recharge model reads the climate data as either time series of rainfall and evaporation data that are recorded at weather stations or as rainfall and evaporation data that are in gridded format. The Input data required by the model to calculate potential recharge are: distributed daily rainfall and 
potential evaporation (climate data), landuse, topography, soil properties, hydrogeological properties, and river network. These different layers of data, except the climate data, are usually prepared in a Geographic Information System (GIS) environment and then converted to gridded ASCII text files. When initiating the numerical model, the model reads these standard formatted ASCII gridded data and distributes the spatial characteristics of the study area across the grid nodes according to their location.

Figure 2 shows a summary of the steps applied by the model to perform a recharge simulation. The model reads control files to setup the grid, to discretise the time, and to set the output files. The model also reads the data layers giving information about rainfall, potential evaporation, and other characteristics of the study area such as topography, landuse, etc. During each time step, the grid node retrieves information from the data layers based on its position ( $X$ and $Y$ coordinates) and time (day, month and year). Soil moisture status is then assessed according to the acquired data and the soil moisture calculated in the previous time step. If recharge and overland flow are generated at one node, recharge is passed to the unsaturated zone where it is held as potential recharge and overland flow is passed downstream until a surface water feature is reached.

\section{Model setup}

The study area was discretised into $2 \mathrm{~km}$ square cells using 58590 nodes to provide full coverage of the UK mainland. The model is run on a daily time step from $1^{\text {st }}$ January 1962 through to $30^{\text {th }}$ of June 2014.

Daily rainfall raster data ( $1 \mathrm{~km}$ by $1 \mathrm{~km})$, obtained from the Centre for Ecology and Hydrology (CEH), were used to retrieve the daily rainfall values at the grid nodes. Figures 3a shows the distributed long term average rainfall values calculated over the study area for the period 1962 to 2002. On average, the east of the study area receives the lowest rainfall up to $720 \mathrm{~mm} / \mathrm{year}$. The west of the study area receives rainfall values that are much higher with long-term average rainfall as high as $3600 \mathrm{~mm} /$ year over the mountains and hills of west Scotland, northwest England, and Wales. The monthly potential evapotranspiration (PE) raster datasets ( $40 \mathrm{~km}$ by $40 \mathrm{~km}$ ) were gathered from a Met Office Rainfall and Evaporation Calculation System (MORECS) in the Met Office of UK (Hough and Jones, 1997). Figure $3 \mathrm{~b}$ shows the distributed long term average potential evaporation data calculated for the period 1962 to 1992 . Highest potential evaporation rates are observed to the east and west of England, in general, and at the square covering the east of London in particular. The middle part of England and Wales has slightly lower potential evaporation rates (610 mm/year), and these decrease gradually towards north of Scotland ( $460 \mathrm{~mm} / \mathrm{year}$ ).

The soil type at every model node is specified using the HOST soil data map which includes 33 classes of soil types (Boorman et al., 1995). The values of the soil parameters, the moisture content at field capacity and the permanent wilting point, are used to calculate the total available water (Equation 1) for plants to evaporate and the readily available water (Equation 2) that plants can evapo-transpire at full rate. The values of these parameters are identical to those used by Griffiths et al. (2008). The difference between the soil moisture content at field capacity and the soil moisture content at wilting is also referred to as soil water capacity (SWC). Figure $3 \mathrm{~d}$ shows the spatial distribution of the SWC across the study area.

Land use data were obtained from the $1 \mathrm{~km}$ by $1 \mathrm{~km}$ Land Cover Map LCM2000 (Natural Environmental Research Council, 2000), which contains 10 different classifications of landuse. This gridded format dataset gives spatially distributed percentage values of the landuse classes within each grid cell. Figure 4 shows a plot of the dataset for seven classes aggregated over the resolution 
of model grid. These are: broad-leaved/mixed woodland, coniferous woodland, arable and horticulture, grassland, semi-natural grass, mountain, heath, and bog, and built up areas. The last three classes are related to open water, coastal, and oceanic. Table 2 shows the values of the root depth constant and depletion factor of these landuse types.

The digital elevation model ( $50 \mathrm{~m}$ by $50 \mathrm{~m}$ ) obtained from CEH was used and re-sampled by averaging the elevations to a resolution of $2 \mathrm{~km}$ by $2 \mathrm{~km}$ to match the resolution of the recharge model grid. Information from this dataset is processed by the recharge model to calculate topographical gradients in the eight directions of the compass at every grid node. When runoff water is generated, this water is routed to a downstream node according to the steepest topographical gradient calculated at the node. The runoff coefficient, however, has to be specified at the grid nodes (Figure 3c). The digital hydrogeological map (Figure 5a) derived from the 1:625000 digital solid geology map (Figure 5b), and the 1:625000 digital superficial deposit map (Figure 5c) for the UK, obtained from the British Geological Survey (BGS), were used to create run-off zones. While each node may contain different zones with different superficial characteristics, the node is allocated a runoff behaviour obtained from either the hydrogeological map or the superficial map depending on the coordinates of the centre of the node. The runoff coefficient values specified at these zones are calculated and refined by model calibration. However, the simplified approach used to create the runoff zones together with the high spatial resolution used to route the runoff affects the accuracy of runoff values over small, upland and topographically variable catchments. The calibration exercise focuses, therefore, on catchments with large areas.

The river network is also included in the model to collect the water generated overland (runoff). The UK river networks as presented by the maps of the Hydrometric Register and Statistics books, and provided by CEH (NERC, 2003), are used to create the numerical rivers in this model (Figure 1). Runoff is simulated using a one-day time step, which is believed to be sufficiently large for overland flow, the fast flow component of the total river flow, generated over one cell to reach the water features such as lakes and rivers. Runoff recharge (indirect recharge), is not simulated in this study since this process cannot be represented at this grid resolution. In addition, the model does not simulate the slow flow component (baseflow) of the total river flow, i.e. groundwater discharge to rivers and flow through the soil zone. It is, however, that the choice of baseflow separation method and the uncertainty associated with it may mask some of these processes.

\section{Model calibration}

The calibration of the recharge model was performed by comparing the simulated overland flows at selected gauging stations to the observed flows. The Hydrometric Register and Statistics books published by the Centre of Ecology and Hydrology (NERC, 2003) give flow details at more than 1500 gauging stations distributed over the UK. However, it was not possible to include all the gauging stations in the calibration of the model. This is because one model node may contain more than one gauging station due to the selected grid resolution. In total 56 gauging stations, the locations of which are illustrated in Figure 1, are selected to calibrate the model. These were chosen to represent the major river basins in the UK with reliable, long-term records. On average, the selected grid resolution has created a $4 \%$ difference between the actual and simulated catchment areas. The size and shape of the catchment is the main cause of this difference with smaller catchments showing great differences than large catchments. For example, the difference between simulated and actual areas of a couple of catchments that are smaller than $300 \mathrm{~km}^{2}$ reaches approximately $20 \%$. 
Because the recharge model ZOODRM does not account for groundwater flows, only the surface water component of the total are used in the calibration of the model. The produced recharge values are then compared to recharge values over parts of the study area available from previous studies. Further refinements are undertaken if the discrepancies are large.

The Institute of Hydrology low flow method (Gustard et al.,1992) was used to separate the observed total river flows into two components, the fast overland flows component (runoff), and the slow flow component (baseflow). In general the fast component occurs within 24 hours and can be seen as a flashy response, whereas the slow component (baseflow) is the return of rainfall to the rivers via the groundwater system. This has a range of timescales depending on whether interflow occurs, but is typically of the order of 10s - 100s days. In general, the period of river flow record spans for more than 40 years. The simulation period for calibration is selected, therefore, from 1962 to 2002 which is assumed to be adequate to reproduce the long term average values reported by the Hydrometric Register.

ZOODRM calculates overland flows from the volume of excess water calculated after accounting for evapo-transpiration and soil moisture deficit. This excess water is divided into potential recharge and overland flow, also referred to as runoff, based on runoff coefficient values. The characteristics of the superficial geology and the hard rock, where they are exposed, affect the amount of excess water infiltrating into the ground and the amount of generated overland flows. The outcrop of the Cretaceous Chalk aquifer, for example, tends to produce small amount of overland flows and allow high infiltration of rainfall, conversely, Eocene Clay deposits tend to generate high runoff flows and to significantly limit recharge to the aquifers underlying them. It must be noted, however, that the mechanism of runoff-recharge, or recharge caused by overland flow generated over low permeability zones and infiltrating at the margins of these zones, is not simulated here. This mechanism could be important when calculating recharge for small catchments; however, it is expected that its omission from this study is not going to cause major errors at this scale. Base flow indices (BFI) reported in the literature, e.g. Bloomfield et al. (2009), Holman et al. (2011) can be used to inform the selection of runoff coefficient values.

There are a number of sources of superficial deposits and their nature. Griffiths et al. (2011) provides classes of recharge potential ranging from very low to very high for the superficial deposits across the UK. Dearden (2016) developed a BGS product related to ground suitability for infiltration sustainable urban drainage systems across the UK, in which a map showing classes of potential infiltration was also developed. In this study the 1:625000 hydrogeological map (Figure 5a) was used to define runoff zones for bedrock outcrops (7 zones). The 1:625000 superficial geology map (Figure $5 \mathrm{c}$ ) was used to define the runoff zones for the superficial deposits (14 zones). The initial runoff coefficient values were assigned to the runoff zones based on the permeability of the bedrocks and superficial deposits making sure that they satisfy the classes identified by Griffiths et al. (2011) and Dearden (2016). In practice, however, the runoff coefficient values for different runoff zones needed tuning to improve the match between the simulated and observed flows. The runoff coefficient values are identified based on the following criteria:

1) Catchments where one major runoff zone can be identified are studied first. The runoff coefficient value of this runoff zone is set to 1 minus the recorded baseflow index at the corresponding river gauging station.

2) Catchments with two major runoff zones are then targeted. Assuming that the sum of the runoff coefficient values multiplied by the percentage of the runoff zone in the catchment is equal to 1 minus the recorded baseflow index at the gauging station, the unknown runoff coefficient value is 
calculated after substituting by the runoff coefficient values calculated in step 1 . The same is then applied to catchments with many runoff zones.

3) To overcome the problem of high degrees of freedom and the non-uniqueness of the solution, a sensitivity analysis exercise was carried out to study the impact of each runoff zone on the overall calculated overland flows. Two additional runs were performed for each runoff zone. In the first run, the runoff coefficient value is increased by $50 \%$ and in the second it is decreased by $50 \%$. Only one runoff coefficient value was changed in each run but the root mean square errors (RMSE, Equation 6) between the simulated LTA surface water flows and the observed ones were calculated at all gauging stations. This produced 3 RMSE values for three runoff coefficient values of each runoff coefficient zone. It was expected that the plot of these RMSE values versus the runoff coefficient values allows the selection of a runoff coefficient value for a corresponding zone that minimises the RMSE value. The RMSE value is given by:

$\operatorname{RMSE}=\sqrt{\sum_{i=1}^{N}\left(V_{O b s}-V_{\text {Sim }}\right)^{2} / N}$

Equation 6

where $V_{O b S}$ is the observed surface flow, $V_{\text {Sim }}$ is the simulated surface flow, and $N$ is the number of samples for comparison, which in this case is equal to the number of selected gauging stations.

Figure 6 shows the plots of RMSE values against the runoff coefficients for 4 selected zones. This shows that all RMSE values decrease with the decrease of the runoff values and indicates that almost all runoff coefficient values used in the initial run were overestimated. 19 out of the 21 plots showed this behaviour with only two plots showing the possibility of selecting runoff coefficients that minimise the RMSE value. Following the sensitivity analyses, the runoff coefficient values were set to the minimum values. In addition, some runoff zones were divided into sub-runoff zones during the calibration process to improve the simulated runoff flows. This highlights the fact that the national scale hydrogeological and geological maps (1:625000), used for defining the runoff zones in this study, might not be able to reflect the actual hydrological conditions in some surface water catchments. For example, the runoff zone representing sand and gravel and the runoff zone representing fissured low productive aquifer, which are covering a large area in Scotland and Wales (Figure 5a), needed to be further classified to improve the match between the simulated and observed runoff. Additional runoff zones, representing the low yielding aquifers in Scotland, and the sand and gravel to the southeast of England were introduced in the runoff zone maps. The spatial distribution of runoff coefficient values obtained after the calibration exercise is shown in Figure 3c.

\section{Results and discussion}

To assess the quality of the model results, the simulated potential recharge values, runoff values, and soil moisture deficit (SMD) values were compared to values reported in the literature. The recharge values are compared to those obtained from three models previously prepared by BGS and to recharge values reported by the Environment Agency (EA). Long term average (LTA) runoff values were compared to LTA observed runoff values at 56 gauging stations, and to investigate seasonal variations of calculated runoff values, simulated monthly long term average runoff values were compared to the observed ones at four gauging stations. Finally, SMD time series are compared to values calculated by the Meteorological Office at three specified locations.

Figure 7 shows a comparison between the simulated and observed long term average runoff values at the 56 gauging stations shown as small blue dots in Figure 1. Ideally, the points of the scatter plot shown in Figure 7 should fall along the solid line which represents a perfect match between the simulated and observed results. In general, the model underestimates the runoff values especially 
those above $20 \mathrm{~m}^{3} / \mathrm{sec}$. However, the overall match is still very good as illustrated by the dashed line in Figure 7. The Pearson correlation coefficient describing the fit of the data is equal to 0.94 .

Figure 8 shows a comparison between the monthly simulated and observed overland flows recorded at the four gauging stations shown as red circles in Figure 1. These gauging stations are River Clyde at Daldowie, River Severn at Hawbridge, River Thames at Kingston and River Eden at Sheepmount. The catchment areas upstream of these gauging stations are shown by the blue polygons in Figure 1 . The catchment upstream of Daldowie at the Clyde (Scotland) has an area of $1903 \mathrm{~km}^{2}$, and an average rainfall of $3.12 \mathrm{~mm}$ day ${ }^{-1}$. The catchment upstream of Hawbridge at the Severn covers parts of the Midlands in England and parts of Wales. It has an area of $9895 \mathrm{~km}^{2}$, and an average rainfall of $3.12 \mathrm{~mm}$ day $^{-1}$. The catchment upstream of Kingston at the Thames covers a large part of the Thames Basin in the south of England. It has an area of $9948 \mathrm{~km}^{2}$ and an average rainfall of $1.97 \mathrm{~mm}$ day $^{-1}$. The catchment upstream of Sheepmount at the Eden covers part of the Eden Valley in North England. It has an area of $2286.5 \mathrm{~km}^{2}$ and an average rainfall of $3.17 \mathrm{~mm}^{-1} \mathrm{day}^{-1}$. Table 3 shows the mean flows and the flow indices as reported by the Hydrometric register (CEH, 2000). Figure 8 shows that the seasonal variations in the generated overland flows are well captured by the recharge model especially at Daldowie (Clyde). While the match between the simulated and observed runoff values is satisfactory at Hawbridge and Kingston gauging stations, the plots of flows at these stations show that the recharge model slightly overestimates the overland flows during the wet months and underestimating the flows during the dry months. The simulated flows are higher than the observed for all months at Sheepmount gauging station. Table 4 shows the water balance of the different components simulated by the recharge model over these four catchment areas.

The simulated distributed groundwater recharge estimates were compared to the recharge estimates simulated at three regional areas using recharge models with smaller grid resolutions. The three selected areas are shown by the brown polygons in Figure 1. These areas are: The Clyde basin and the Dumfries basin in Scotland, and the Marlborough Berkshire Down area in the Thames Basin in England. The Clyde Basin recharge model (Campbell et al., 2010, Turner et al., 2015) is developed using a grid of $1 \mathrm{~km}$ square cells. The area of the Clyde basin is approximately $3100 \mathrm{~km}^{2}$. The Dumfries basin recharge model has an area of approximately $210 \mathrm{~km}^{2}$. The model grid has $500 \mathrm{~m}$ spacing in the $X$ and $Y$ direction and the recharge is calculated over the period from 1970 to 2003 (Jackson et al., 2005). The Marlborough Berkshire Down model calculates recharge on three grid levels (Jackson et al., 2011). The middle grid level which has a resolution of $500 \mathrm{~m}$ square cells was used in this study. This grid has an area of approximately $1500 \mathrm{~km}^{2}$. All these recharge models apply the Penman and Grindley recharge calculation algorithm (Penman, 1948, Grindley, 1967) that calculates recharge using rainfall and potential evaporation values and using the crop characteristics represented by the root constant and the wilting point. In addition, and unlike the approach used here, these models calculates runoff as a percentage of rainfall before accounting for evapotranspiration.

Figure 9 shows the histograms of the differences between the recharge values calculated in this study and those from the three existing recharge models. Recharge values calculated for the Marlborough Berkshire Down area produce the best match while the match is poorest for the Dumfries Basin. The main reasons for the discrepancies are the grid resolution, which has an impact on the specification of the topographical characteristics and land use at the grid nodes, and the different recharge calculations methods applied in the regional models and the UK-wide recharge model. One additional and important cause for the differences between the recharge values calculated in the Dumfries basin is an area of peat, which is underlain by clays and has limited vertical downwards movement of water to the saturated zone (see Fig 3; Jackson et al., 2005). This 
was simulated in the regional model by a high runoff coefficient values resulting in very low recharge values (close to zero) at these areas. The national scale recharge model used here does not account for this process, rather it includes the potential recharge calculated over the peat.

The recharge values estimated by the recharge model ZOODRM were compared to the long-term average recharge attributed to groundwater bodies as estimated by the Environment Agency (EA). The EA datasets contain recharge values over England and Wales mapped from the surface water body estimates using the matrix of surface water body areas as percentage of groundwater bodies they intersect or overridden by local area staff (https://data.gov.uk/dataset/groundwater-bodieslong-term-average-recharge-mm-a). The estimated recharge values calculated in this study were averaged over the area of the groundwater bodies and then compared to the values provided by the EA. Figure 10a shows the spatial distribution of the percentage relative difference between the recharge values calculated by ZOODRM and those estimated by the EA as absolute values. The higher differences occur in the east of the country and may be due to the impact of complex superficial deposits. Figure $10 \mathrm{~b}$ shows a histogram of the recharge differences indicating that, on average, the EA values are greater than ZOODRM calculated values (between 0 and $0.2 \mathrm{~mm}$ day $^{-1}$ ). Figure 10c provides a scatter plot showing a comparison between the ZOODRM derived and EA recharge values. The match is acceptable as illustrated by the dotted trend line of the time series and the Pearson correlation coefficient of 0.78. The scatter plot (Figure 10c) shows that at lower values, the ZOODRM estimates are lower than the EA estimates. It must be noted that the recharge values provided by the EA are calculated using different approaches and at different times; they were not obtained from one model or one recharge assessment methodology. Results from a benchmarking exercise with results published in the literature and regional EA models are discussed below. However, the comparison with the EA was useful to highlight areas where additional model refinement may be necessary. Of particular note are the differences observed in the east of England and central and north-west England. These are likely to result from the influence of glacial deposits modifying potential recharge before it becomes actual. As discussed below, the inclusion of Quaternary deposits and their influence on recharge processes is one of the next stages in the development of the model. However, given the consistency of the approach over the UK mainland the model can be thought of as fit for purpose, i.e. being able to answer water resource questions at a catchment scale on a national basis.

The recharge model calculates the soil moisture deficit (SMD) as a by-product. In order to assess the performance of the model, the time series of SMD values produced in this study were compared to those calculated by the United Kingdom Meteorological Office rainfall and evaporation calculation system MORECS version 2.0 (Hough and Jones, 1997). MORECS provides estimates of evaporation, SMD and effective precipitation using a crop model similar to the EA/FAO method. It uses daily weather data to provide estimates of weekly and monthly evaporation and SMD values using a grid with $40 \mathrm{~km}$ square cells. Figure $2 \mathrm{~b}$ illustrates the resolution used in the MORECS system. The calculation was undertaken using a landuse typical of the 1990s and measured soils data were used to find ranges of available water capacities (AWC) values for the different crops. However, the AWC values were computed at a $1 \mathrm{~km}$ resolution and for each crop the median, 10 and 90 percentile AWC values were calculated in each cell. Time series of SMD values produced by MORECS using the 90 percentile AWC values were used in this study.

Figure 11 shows the comparison between the temporal variations of SMD values calculated by MORECS and ZOODRM at three MORECS squares 65, 108, and 159 (Figure 3b) over the period from 1980 to 1989 . The grid resolution of ZOODRM, $2 \mathrm{~km}$ square cells, is much higher than that of MORECS, so there are 400 ZOODRM SMD values for every MORECS square. The black lines in 
Figure 11 show the SMD time series as calculated by MORECS. The blue lines show the time series produced by averaging the 400 ZOODRM SMD values calculated at a square at a given time step, and the red lines represent the SMD time series calculated using the maximum value among the 400 SMD values calculated by ZOODRM for one square. While the timing of the two time series match, it is clear that the average ZOODRM SMD values are lower than the MORECS SMD values at all three squares. The approach of accounting of runoff after that the SMD reaches zero, i.e. providing more water to the soil, used in this model could be the cause of this smaller SMD fluctuations. However, the MORECS SMD time series were calculated using the $90^{\text {th }}$ percentile AWC values and this allows for higher evaporation from the soil. In addition, the red lines, showing the maximum SMD values calculated by ZOODRM within a square, are almost always higher than the values of the black lines (MORECS) at the three squares and showing that there is a good match between SMD values calculated by these two models.

\section{Benchmarking outputs}

To better appreciate how the recharge model performs against other modelled results, recharge values were obtained from the peer reviewed literature along with EA model outputs. A range of geographical locations from Scotland and the south, west and east of England representing different climate conditions and land use were identified (see Figure 12 and Table 5). Two sets of results are available. The first set includes point recharge values at Paisley, Coltishall, and Gatwick (HerreraPantoja and Hiscock, 2007), and at Bridgets Farm, Fleam Dyke, Bicton College, and Bacon Hall (Ragab et al. 1997). The second set includes distributed recharge values over catchments of a range of sizes reported by the EA and in the literature. A sub-set of EA recharge models has been used for benchmarking in this study and were chosen to ensure that the major aquifers were chosen and that there is a suitable geographical spread. The catchments which have distributed recharge are as follows: The North Norfolk model in the east of England has an area of $2250 \mathrm{~km}^{2}$ of confined and unconfined Chalk and areas with thick boulder clay cover (Yusof et al., 2002). The Pang catchment has an area of $171 \mathrm{~km}^{2}$ and is situated on the dip of the Chalk aquifer in the centre of south England (Bradford et al., 2002). The North Lincolnshire model in the east of England occupies an area of approximately $350 \mathrm{~km}^{2}$ of unconfined Chalk (Hutchinson et al., 2012). The South Wessex model in the south of England occupies an area of approximately $2260 \mathrm{~km}^{2}$ of unconfined Chalk (Whiteman et al., 2012). The Lark and Waveney catchments in the east of England with an area of $461 \mathrm{~km}^{2}$ and 890 $\mathrm{km}^{2}$ respectively (Black et al., 2012). The lark comprises of exposed Chalk and Glacial deposits, whereas Waveney is characterised by Glacial Deposits covering most of the Chalk outcrop geology. The Ely Ouse (Environment Agency, 2008a) and the Lower Little Ouse (Environment Agency, 2008b) models located between the Lark, Waveney and North Norfolk areas, have areas of 324 and $500 \mathrm{~km}^{2}$ respectively and consist of Chalk covered with blown sand and gravel as well as glacial deposits. Recharge over the Mole catchment (Environment Agency, 2008c) has a reported area of $2270 \mathrm{~km}^{2}$ and is calculated over the Chalk but also over the Upper and Lower Greensand aquifers. The lower Mersey Basin (ESI, 2009) has an area of $880 \mathrm{~km}^{2}$ and covers the Permo-Triassic sandstone aquifer. The Birmingham model (ESI, 2014) has an area of $295 \mathrm{~km}^{2}$ and comprises mainly of Sherwood Sandstone aquifer. The East Yorkshire model (ESI, 2015) has an area of $1980 \mathrm{~km}^{2}$ and comprises of Chalk that is partly covered by glacial deposits. The results from the study presented here were compared for the correct timescale to ensure that the values obtained were not influenced by climatic variation.

521 The comparison was rated from very good ( $<1 \%$ difference), good ( $1-10 \%$ difference), adequate 522 (10-20\% difference) and poor (>20\% difference) based on the percentage difference in brackets. In general, the comparisons are adequate to very good. This is particularly the case for the 
distributed recharge comparisons with the exception of the North Lincolnshire, the Lark, Lower Mersey Basin, Birmingham, and the Waveney models. The issue with the North Lincolnshire model is that it is effectively a single point model applied over an area of approximately $350 \mathrm{~km}^{2}$. This model has been superseded by the Environment Agency. For the Lower Mersey Basin, the reported recharge values are calculated over nodes with no impermeable surfaces. As for the Waveney catchment, the water balance output showed that there are significant differences in the calculated overland flow, with the one calculated in this study being higher than that reported in the literature. By reducing the runoff coefficient value of the zone representing tills, the calculated LTA recharge value (value in bracket in Table 5) becomes close to that reported. However, this runoff zone extends to the north and covers significant part of study area, mainly Scotland. The modification of the runoff coefficient value has consequently affected the calculated river flows elsewhere in the study area. As suggested earlier, this highlights the need to subdivide the runoff zones because the characteristics of the materials used to define the zones may vary nationally. As for the Lark catchment, the current calculations produce recharge value that is lower than that reported for this catchment. This is due to the calculation of the actual evapotranspiration. There are two possible causes for producing different evapotranspiration rates. First is the different approaches used to account for overland flows. This study account for runoff after satisfying the soil moisture deficit and this provides more water for the plants to evapo-transpire while the EA model account for runoff as a fraction of the rainfall. Second, this study uses MORECS potential evaporation data rather than the MOSES potential evaporation data used in the EA model. Quinn et al. (2012) mention that "in eastern and southern England, annual MOSES PE totals are typically 10 to $20 \%$ lower compared with MORECS" and this will consequently have an impact on the calculated recharge value.

The comparison of point recharge calculations is mainly poor or adequate. The mismatch between the reported and calculated recharge values is mainly due to the difference in the specification of land use in this study and in the model reported in the literature at the point. This heavily modified the recharge calculation and Table 5 details the difference in land use used at the ZOODRM nodes. For example Bridgets Farm is the best comparison between ZOODRM and the literature value, and was calculated using with a grass land use for which the ZOODRM node has grass as the majority of land use. The comparison at Bacon Hall, on the other hand, is poor and this is because this model specifies Arable and Woodland landuse, whereas the literature model uses grass. This exercise, given that it is a "blind test" of the model and completed after calibration, shows that recharge values compare favourably with the range of values presented in the literature.

Figure 13 presents the long-term average potential recharge (LTAPR) calculated by the ZOODRM national scale model between 1962 and 2002. In general, the LTAPR follow a similar spatial pattern to the LTA rainfall (see Figure 3a), i.e. higher in the west of the UK and lower in the east. This is driven predominantly by the spatial variation in rainfall but also by the spatial distribution of potential evaporation which follows the opposite pattern, i.e. highest on the south-east England, lowest in north-west Scotland. The combination of these two factors produces the overall general spatial distribution of LTAPR. However, the LTAPR is much more nuanced than just being driven by rainfall and $P E$. Examining Figure $3 c$ shows how the runoff coefficient, related to the nature of the soils and underlying geology, varies across the UK. The runoff coefficient modifies the LTAPR and this can be observed most strongly in the south-east of England. For example, in the Wealden basin, outcrops of clay are juxtaposed with sandier outcrops and resulting in very low LTAPR values $\left(<0.2 \mathrm{~mm} \mathrm{day}^{-1}\right)$ compared to moderately high ones $\left(>0.81 \mathrm{~mm} \mathrm{day}^{-1}\right)$. The outcrop of the Chalk also produces highly variable LTAPR with higher values $\left(>0.81 \mathrm{~mm} \mathrm{day}^{-1}\right)$ in the western extent versus $>$ $0.2 \mathrm{~mm} \mathrm{day}^{-1}$ in East Anglia, where glacially-derived, clay-rich superficial deposits cover the Chalk. Similarly, the sandstone outcrop, which covers the central part of the UK exhibits low LTAPR values 
in the Mersey area, which is situated in the west of the UK. This is an area of average LTA rainfall but high PE resulting in lower than average potential recharge, exacerbated by a covering of low permeability superficial deposits which promote runoff.

\section{Conclusions}

575 A distributed recharge model has been used to calculate the distribution of long term average 576 recharge values over the UK. A range of hydrogeological, geological, and topographical datasets 577 have been used in a recharge algorithm, the modified EA/FAO56 soil moisture algorithm, to produce 578 the national recharge map. The main challenges faced with estimating recharge at this scale is the 579 representation of the river network and the aggregation of spatial information to a relatively corase 580 grid size. Another challenge is the calibration of the recharge model and validation of results.

581 The calibration of the model is achieved by simulating overland flows, the fast component of the 582 total river flows, that match the observed ones. The large number of runoff zones and the high degree of freedom associated with selecting runoff coefficient values for each of these zones caused the solution to be non-unique. However, addressing the runoff coefficient values at each zone seperately and the graphical approach used to select the optimum values of these coefficients permitted the computation of long term average (LTA) runoff values that are in good agreement with the observed runoff values. LTA monthly estimate of runoff flows are also checked at four gauging stations. While there is agreement between the simulated and observed seasonal variations, it is clear that the calibration process benefits from further refinement of the runoff coefficient values. This highlights the difficulties associated with the calibration of a time variant recharge model, a work that will be addressed in further development of the model.

The estimated recharge values were validated against the recharge values calculated for three higher-resolution regional models in the UK (the Marlborough Berkshire Downs, the Dumfries basin and the Clyde basn models). The differences in the recharge values are small in the Marlborough Berkshire Downs area but significant over the other two areas. The main reason for the differences are the grid resolution, the differences in the used recharge algorithms, as well as the degree of hydrogeological complexity included in each model due to grid resolution. This also applies to the comparison between the recharge values of this study and those provided by the Environment Agency discussed in this paper.

600 The benchmarking exercise shows that recharge values calculated in this study agree with many of the recharge values reported in the literature. Major differences are noted when there are significant differences in the specification of landuse types between models, and when used data, such as potential evaporation data, are different. This exercise also highlighted that there is a need for further refinement of the calculation of overland flows and there is a question about the validity of the method used to account for runoff after filling the soil store and not as a direct percentage of rainfall.

607 The comparison between the time series of soil moisture deficit calculated in this study and those 608 calculated by the MORECS system provided by the MetOffice show an agreement between the timing of occurrence and magnitude of soil moisture deficit (SMD). This exercise show that observed SMD values can be used alongside runoff flows to calibrate the model. Observed SMD values will be used in the improvement of the model in future development. processes that need to be taken into account to improve the quality of the estimated recharge values. These include further calibration to include snowmelt properties, translating potential 
recharge to actual recharge via examining the role of the unsaturated zone and superficial deposits, and others. On going work is being undertaken to marry the recharge model to a groundwater model to produce a complete water balance model and to compare with river baseflows., and, in conjuction with the EA, to include soil processes with a view to investigating the impact of climate change on recharge. This work provides the basis of a UK wide recharge model that, once fully calibrated and validated, can be used to assess available water resources, to answer key questions such as the feasibility of ground couple heat pumps, the regional variation of soil moisture, and the effects of climate change on these resources particularly at the catchment basin scale.

\section{Acknowledgements}

The authors would like to thank the anonymous reviewers and Stephen Buss (Scientific Editor for the Geological Society of London) for their suggestions to improve the manuscript. Mansour, Hughes and Wang publish with the permission of the Executive Director of the British Geological Survey (NERC). This work was supported by the Natural Environmental Research Council [GROMIT project : grant number NE/F018568/1].

\section{References}

Bibby, P. 2009. Land use change in Britain. Land use policy. 10.1016/j.landusepol.2009.09.019

Black, A.D., Lewis, R.T., Grout M.W. \&Witterick, W.R. 2012. Crossing boundaries, the influence of groundwater model boundaries and a method to join and split MODFLOW models. In: Shepley, M.G., (ed.) Groundwater resources modelling: a case study from the UK. London, UK, Geological Society of London, 155-172. (Geological Society Special Publications, 364).

Bloomfield, J.P., Allen, D.J., Griffiths, K.J. 2009. Examining geological controls on Baseflow Index (BFI) using regression analysis: an illustration from the Thames Basin, UK. Journal of Hydrology, 373 (1-2). 164-176, DOI 10.1016/j.jhydrol.2009.04.025

Boorman D.B., Hollist J.M. \& Lilly A. 1995. Hydrology of soil types: a hydrologically-based classification of the soils of the United Kingdom. Institute of Hydrology Report No. 126. Wallingford, UK.

Bradbury, C.G., Rushton, K.R. 1998. Estimating runoff-recharge in the Southern Lincolnshire Limestone catchment, UK. Journal of Hydrology, 211, 86-99.

Bradford, R.B., Ragab R., Crooks S.M., Bouraoui F. \& Peters E. 2002. Simplicity versus complexity in modelling groundwater recharge in Chalk catchments. Hydrology and Earth Systems Sciences, 6(5), 927-937.

Busby, J.P., Entwisle, D., Hobbs, P., Jackson, P., Johnson, N., Lawley, R., Linley, K., Mayr, T., Palmer, R., Raines, M., Reeves, H., Tucker, S., Zawadzka, J. 2012. A GIS for the planning of electrical earthing. Quarterly Journal of Engineering Geology and Hydrogeology, 45 (3) 379-390. 10.1144/1470-9236/11-023

Campbell, S. Diarmad G., Merritt, J. E., O Dochartaigh, B. E., Mansour, M., Hughes, A. G., Fordyce, F M., Entwisle, D. C., Monaghan, A. A.\& Loughlin, S. C. 2010. 3D geological models and their hydrogeological applications : supporting urban development : a case study in Glasgow-Clyde, UK. Zeitschrift der Deutschen Gesellschaft fur Geowissenschaften, 161 (2). 251-262. 10.1127/1860-1804/2010/0161-0251

Cross G.A., Rushton K.R. \& Tomlinson, L.M. 1995. The East Kent Chalk Aquifer during the 1988-92 drought, Journal of the Institute of Water and Environmental Management, 9, 37-48. 
Dearden, R. 2016. User guide for the Infiltration SuDS Map: detailed. Nottingham, UK, British Geological Survey, 32pp. (OR/16/009) (Unpublished). http://nora.nerc.ac.uk/id/eprint/513763

Döll, P. \& Fiedler, K. 2008. Global-scale modelling of groundwater recharge. Hydrology and Earth System Sciences, 12, 863885.

Environment Agency 2008 (a). Phase 3 Project Record for the Ely Ouse Groundwater Resource Investigation Area. Thet Reporting Area, Volume 1: Characterisation of Catchment Behaviour. Entec UK Limited.

Environment Agency 2008 (b). Phase 3 Project Record for the Ely Ouse Groundwater Resource Investigation Area. Lower Little Ouse Reporting Area. Entec UK Limited.

Environment Agency 2008 (c). Mole Catchment Groundwater Conceptual Model development Study. Phase 1 Mole Catchment Conceptual Model Review and Numerical Model Proposals. By Entec UK Limited.

ESI 2009. Lower Mersey and North Merseyside Water Resources Study: Final Report. Volume 1. ESI Ltd for the Environment Agency.

ESI 2014. Birmingham Sherwood Sandstone Aquifer Investigation. Numerical Model Report. Prepared for the Environment Agency.

ESI 2015. East Yorkshire Chalk Aquifer Investigation: Model Update and Recalibration. Report reference: 62986 R2. Prepared for the Environment Agency.FAO, 1998. Crop Evapotranspiration; Guidelines for Computing Crop Water Requirements. FAO Irrigation and Drainage Paper 56, Rome.

Finch J.W. 2001. Estimating change in direct groundwater recharge. Quarterly Journal of Engineering Geology and Hydrogeology, 34 (1), 71-83.

Griffiths, J., Young, A.R. \& Keller, V. 2006. Model scheme for representing rainfall interception and soil moisture. Environment Agency Environment Agency R \& D Project W6-101 Continuous Estimation of River Flows (CERF). UK.

Griffiths, J., Keller, V., Morris, D. \& Young, A.R. 2008. Continuous Estimation of River Flows (CERF). Environment Agency Science Report SC030240. Bristol, UK.

Griffiths, K.J., MacDonald, A.M., Robins, N.S., Merritt, J., Booth, S.J, Johnson D., McConvey, P.J. 2011. Improving the characterization of Quaternary deposits for groundwater vulnerability assessments using maps of recharge and attenuation potential. Quarterly Journal of Engineering Geology and Hydrogeology, 43, 49-61, DOI 10.1144/14709236/09-009

Grindley, J. 1967. The estimation of soil moisture deficits. Meterol. Mag., 96, 1137, 97-108

Gustard, A., Bullock, A. \& Dixon, J. M. 1992. Low Flow Estimation in the United Kingdom. Institute of Hydrology Report No. 108.

Heathcote, J. A., Lewis, R. T., \& Soley, R. W. N., 2004. Rainfall routing to runoff and recharge for regional groundwater resource models. Quarterly Journal of Engineering Geology and Hydrogeology, 37(2), 113-130.

Herrera-Pantoja, M. \& Hiscock, K.M. 2007. The effects of climate change on potential groundwater recharge in Great Britain. Hydrological Processes, 22, 73-86. DOI: 10.1002/hyp.6620

Hess, T.M., Leeds-Harrison, P.B., \& Counsell, C. 2000. WaSim Technical Manual. https://dspace.lib.cranfield.ac.uk/bitstream/1826/2455/3/Technical_Manual.pdf (Accessed 18th October 2013)

Holman, I.P., Hess, T.M. and Rose, S.C. 2011. A broad-scale assessment of the effect of improved soil management on catchment baseflow index. Hydrological Processes, 25, 2563-2572. 10.1002/hyp.8131. 
Holman, I.P., Tascone, D., Hess T.M. 2009. A comparison of stochastic and deterministic downscaling methods for modelling potential groundwater recharge under climate change in East Anglia, UK: implications for groundwater resource management. Hydrogeology Journal, Volume 17, Issue 7, pp 1629-1641

Hough M.N. \& Jones R.J.A. 1997. The United Kingdom Meteorological Office rainfall and evaporation calculation system: MORECS version 2.0 - an overview. Hydrology and Earth System Sciences 1 (2) :227-239.

Hughes A.G., Mansour M.M. \& Robins NS. 2008. Evaluation of distributed recharge in an upland semi-arid karst system: the West Bank Mountain Aquifer. Hydrogeology Journal. 10.1007/s10040-008-0273-6.

Hulme, P., Rushton, K., \& Fletcher, S., 2001. Estimating recharge in UK catchments. IAHS PUBLICATION, 33-42.

Hulme P., Grout M., Seymour K., Rushton K., Brown L. \& Low R. (2002) Groundwater resources modelling: guidance notes and template project brief (Version 1). Environment Agency, Bristol, U.K.

Hunter Williams, N.H.., Misstear, B.D.R., Daly, D., Lee, M. 2013. Development of a national groundwater recharge map for the Republic of Ireland. Quarterly Journal of Engineering Geology and Hydrogeology, Vol. 46, 2013, pp. 493-506. doi: 10.1144/qjegh2012-016

Hutchinson, M.J., Ingram, R.G.S., Grout M.W. \& Hayes, P.J. 2012. A successful model: 30 years of the Lincolnshire Chalk model. In: Shepley, M.G., (ed.) Groundwater resources modelling: a case study from the UK. London, UK, Geological Society of London, 85-98. (Geological Society Special Publications, 364).

Jackson, C.R., Meister, R. \& Prudhomme, C. 2011. Modelling the effects of climate change and its uncertainty on UK Chalk groundwater resources from an ensemble of global climate model projections. Journal of Hydrology, 399 (1-2). 12-28. 10.1016/j.jhydrol.2010.12.028

Jackson, C.R., Hughes, A.G., Ó Dochartaigh, B.É., Robins, N.S., Peach, D.W. 2005. Numerical testing of conceptual models of groundwater flow: a case study using the Dumfries Basin aquifer. Scottish Journal of Geology 41, (1), 51-60.

Lerner, D.N., Issar, A. \& Simmers, I. 1990. Groundwater recharge; a guide to understanding and estimating natural recharge. International Contributions to Hydrogeology 8, Heise, Hannover, Germany.

Mansour M.M., Barkwith, A. \& Hughes, A.G., 2011. A simple overland flow calculation method for distributed groundwater recharge models. Hydrological Processes, 25 (22). 3462-3471. 10.1002/hyp.8074

Mansour, M.M.; Hughes, A.G. 2014 Land use, climate change and water availability: preliminary modelling of impacts of climate change and land use change on groundwater recharge for England and Wales. Nottingham, UK, British Geological Survey, 53pp. (OR/14/018) (nora.nerc.ac.uk/507537/)

Mansour, M.M. \& Hughes, A.G. 2004. User's manual for the distributed recharge model ZOODRM. British Geological Survey Report No. IR/04/150 (Unpublished).

Natural Environment Research Council (NERC) 2000. Countryside Survey 2000 Module 7. Land Cover Map 2000 Final Report. Centre for Ecology and Hydrology, Wallingford, U.K.

Natural Environment Research Council (NERC) 2003. Hydrological data United Kingdom, Hydrometric register and statistics 1996-2000. Centre for Ecology and Hydrology, Wallingford, U.K.

O Dochartaigh, B.E., MacDonald, A.M., Darling, W.G., Hughes, A.G., Li, J.X., Shi, L.A. 2010. Determining groundwater degradation from irrigation in desert-marginal Northern China. Hydrogeology Journal, 18 (8). 1939-1952. 10.1007/s10040-010-0644-7

Quinn, S.A., Liss, D., Johnson, D., va Wonderen, J.J. \&Power, T. 2012. Recharge estimation methodologies employed by the Environment Agency of England and Wales for the purposes of regional groundwater resource modelling. Groundwater resources modelling: a case study from the UK. Geological Society, London, Special Publications, 364. 
Penman H.L. 1948. Natural evaporation from open water, bare soil and grass, Proceedings of the Royal Society London, Series A, 193, 120-145

Ragab, R., Finch, J.W. \& Harding, R.J. 1997. Estimation of groundwater recharge to Chalk and sandstone aquifers using simple soil models. Journal of Hydrology, 190, 19-41.

Rushton, K.R., Fletcher W.S. \& Bishop T.J. 1995. Surface water and groundwater components of the Nottinghamshire Sherwood sandstone aquifer system. BHS 5th National Hydrology Symposium, Edinburgh, 2.17 - 2.24.

Rushton K. 1997. Recharge from permanent water bodies. In: Simmers I (ed) Recharge of phreatic aquifers in (semi)arid areas. AA Balkema, Rotterdam, pp 215-255

Rushton K.R. \& Ward C. 1979. The estimation of groundwater recharge, Journal of Hydrology, 41, 345-361.

Shepley, M.G., Whiteman, M.I., Hulme, P.J., \&Grout, M.W. 2012. Groundwater resources modelling: a case study from the UK. Geological Society, London, Special Publications, 364.

Silgram, M., Williams, A., Waring, R., Neumann, I., Hughes, A., Mansour, M. \& Besien, T. 2005. Effectiveness of the nitrate sensitive areas scheme in reducing groundwater concentrations in England. Quarterly Journal of Engineering Geology and Hydrogeology, 38 (2). 117-127. 10.1144/1470-9236/04-010

Scanlon, B.R., Healy, R.W., \& Cook, P. G. (2002). Choosing appropriate techniques for quantifying groundwater recharge. Hydrogeology Journal, 10(1), 18-39.

Tanguy, M., Dixon, H., Prosdocimi, I., Morris, D. G., Keller, V. D. J. (2014). Gridded estimates of daily and monthly areal rainfall for the United Kingdom (1890-2012) [CEH-GEAR]. NERC Environmental Information Data Centre https://doi.org/10.5285/5dc179dc-f692-49ba-9326-a6893a503f6e".

Turner, R.J., Mansour, M.M., Dearden, R., O Dochartaigh, B.E., Hughes, A.G. 2015. Improved understanding of groundwater flow in complex superficial deposits using three-dimensional geological-framework and groundwater models: an example from Glasgow, Scotland (UK). Hydrogeology Journal, 23 (3). 493-506. 10.1007/s10040-014-1207-0

University of Birmingham, 1978. Humberbank salinity study, final report.

Wang, L., Burke, S.P., 2017. A catchment-scale method to simulating the impact of historical nitrate loading from agricultural land on the nitrate-concentration trends in the sandstone aquifers in the Eden Valley, UK. Science of the Total Environment 579, 133-148. DOI: 10.1016/j.scitotenv.2016.10.235.

Wang, L., Stuart, M.E., Lewis, M.A., Ward, R.S., Skirvin, D., Naden, P.S., Collins, A.L., Ascott, M.J., 2016. The changing trend in nitrate concentrations in major aquifers due to historical nitrate loading from agricultural land across England and Wales from 1925 to 2150. Science of the Total Environment 542, 694-705. DOI:10.1016/j.scitotenv.2015.10.127

Whiteman, M.I., Seymour, K.G., van Wonderen, J.J. Maginness, C.H., Hulme, P.J., Grout, M.W. \&Farrell, R.P. 2012. Start, development and status of the regulator-led national groundwater resources modelling programme in England and Wales. In: Shepley, M.G., (ed.) Groundwater resources modelling: a case study from the UK. London, UK, Geological Society of London, 19-37. (Geological Society Special Publications, 364).

Yusof, I., Hiscock, K.M. \&Conway, D. 2002. Simulation of impacts of Climate change on groundwater resources in eastern England. In: Hiscock, K.M., Rivett, M.O. \& Davison, R.M. (eds.) Sustainable Groundwater Development. Geological Society of London, 325-344. (Geological Society Special Publications, 193). 


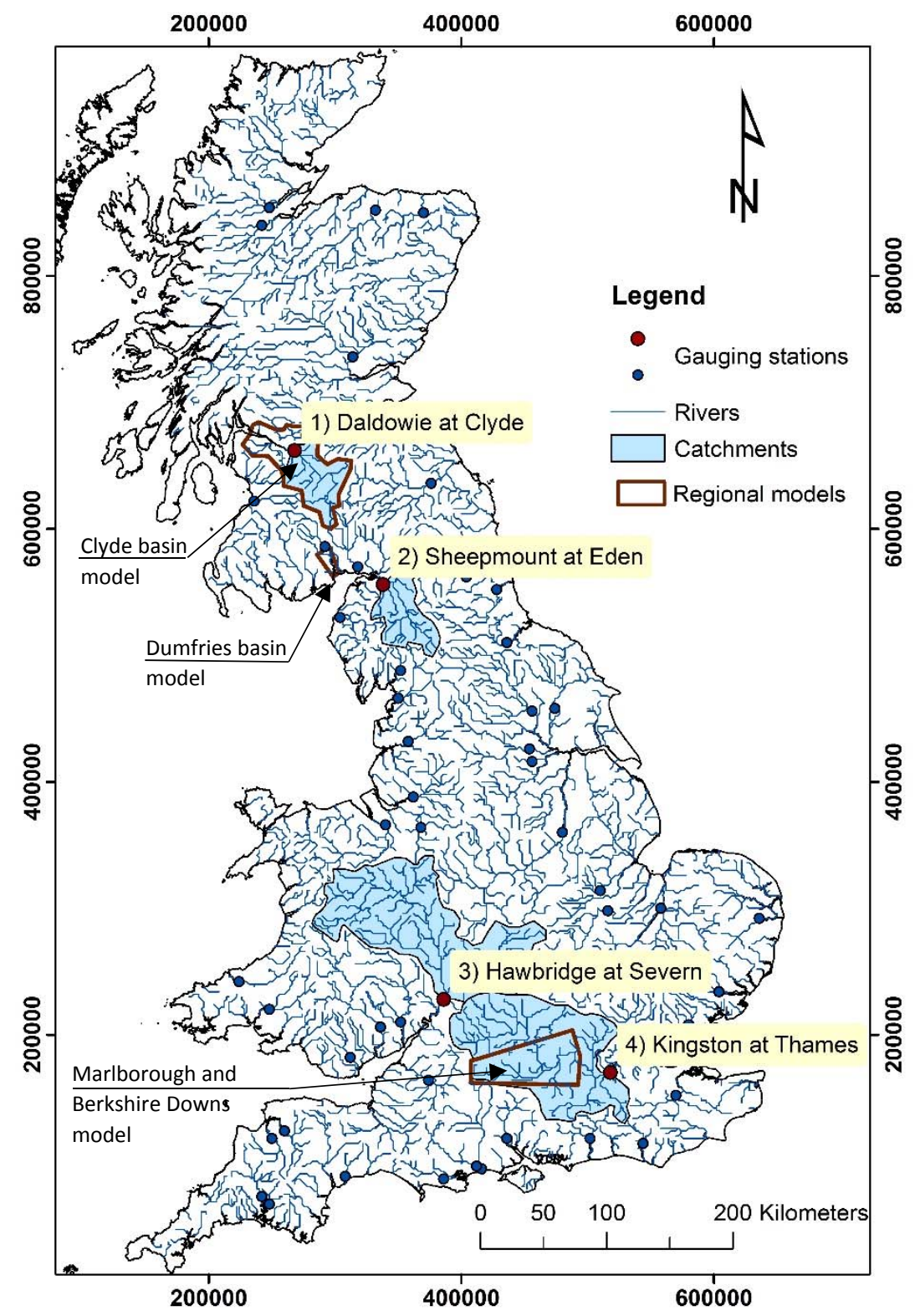

771 Figure 1 Extent of the study area, the river network and the locations of river gauging stations.

772 "Contains Ordnance Survey data (C) Crown Copyright and database rights 2014" 
Model Initialisation

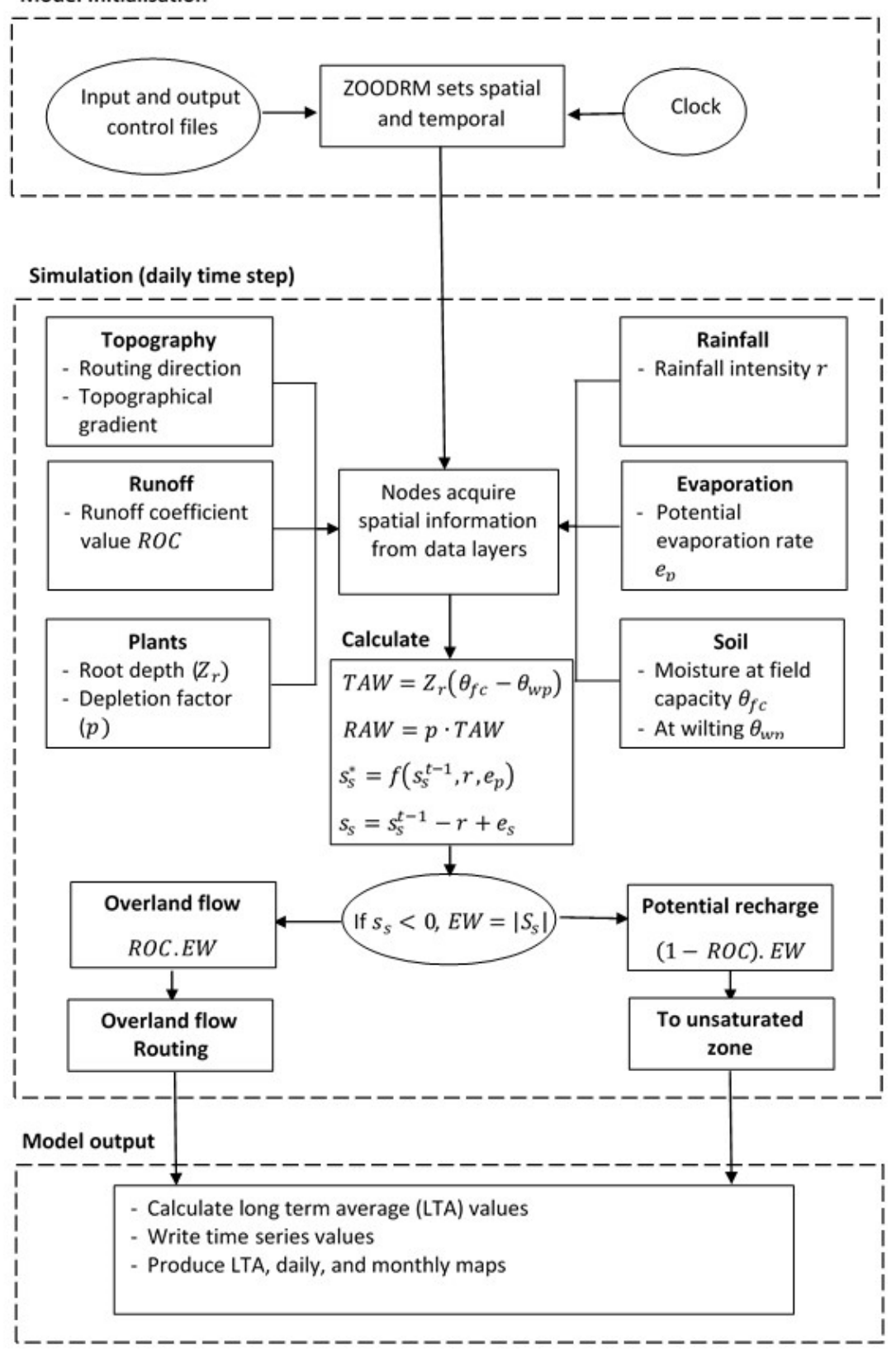

Figure 2 Diagram showing steps followed to estimate recharge values. 


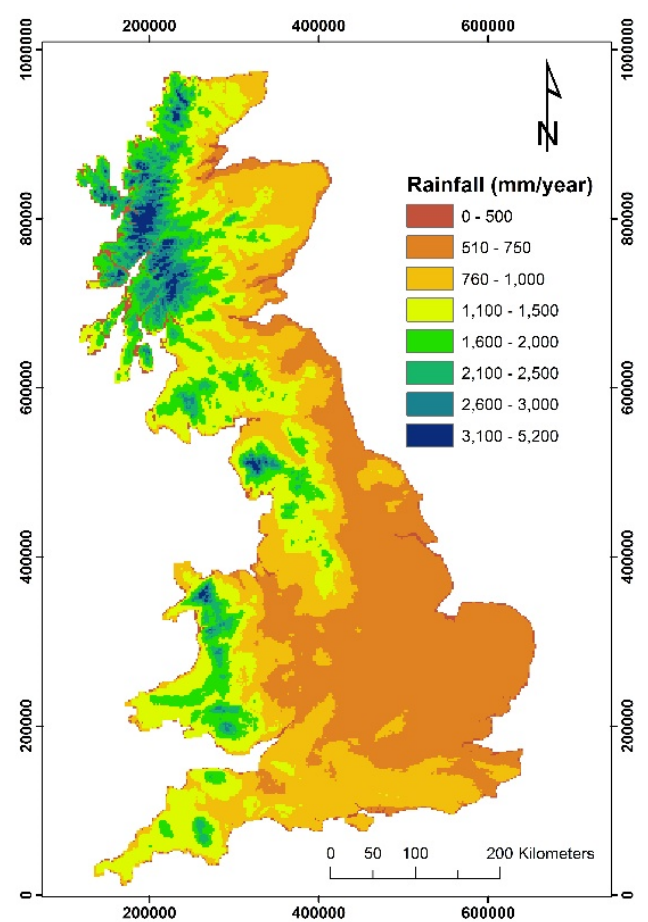

(a)

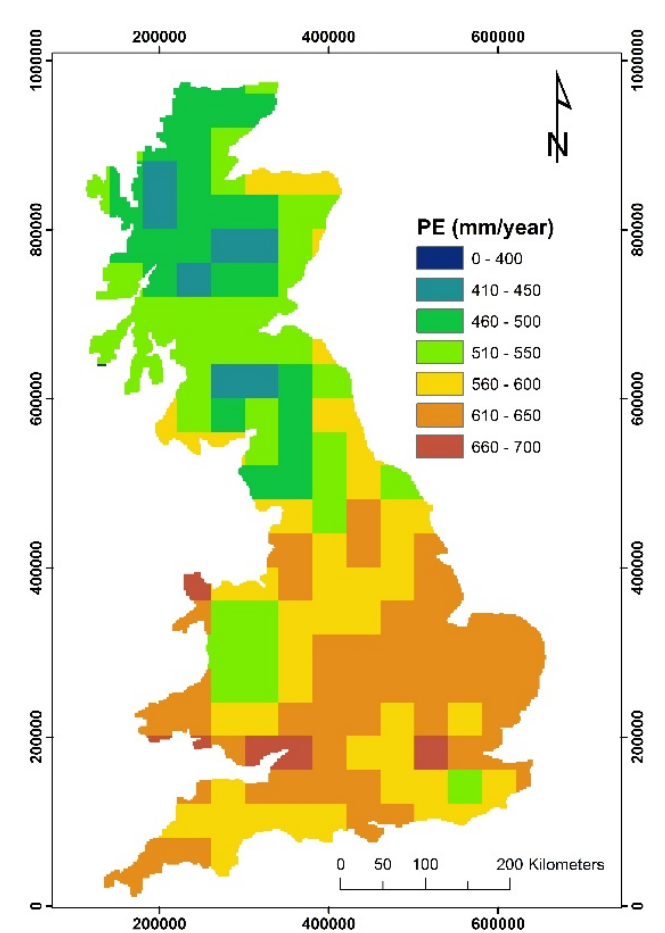

(b)

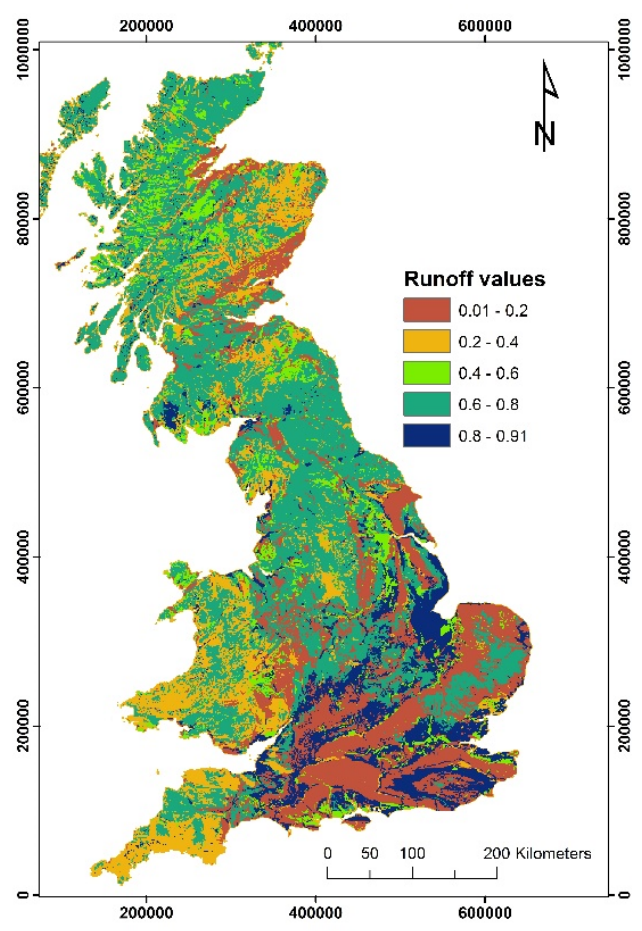

(c)

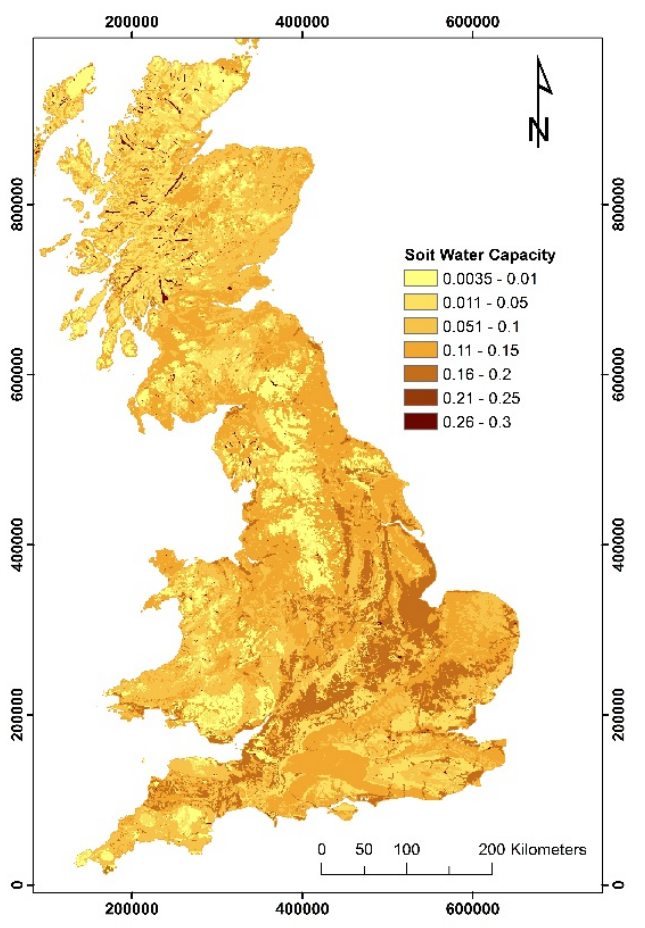

(d)

Figure 3: Spatial distribution of: a) rainfall (NERC, Tanguy et al. (2014)), b) potential evaporation (MetOffice licence reference number 010045532), c) runoff, and d) soil water capacity across the study area derived from land use dat (NERC, 2000) and soil data (Boorman et al., 1995). 
789

790

791

792

793

794

795

796

797

798

799

800

801

802

803

804

805

806

807

808

809

810

811 Figure 4 Spatial distribution of land use types across the study area (after Boorman et al., 1995)

812

813

814

815

816 

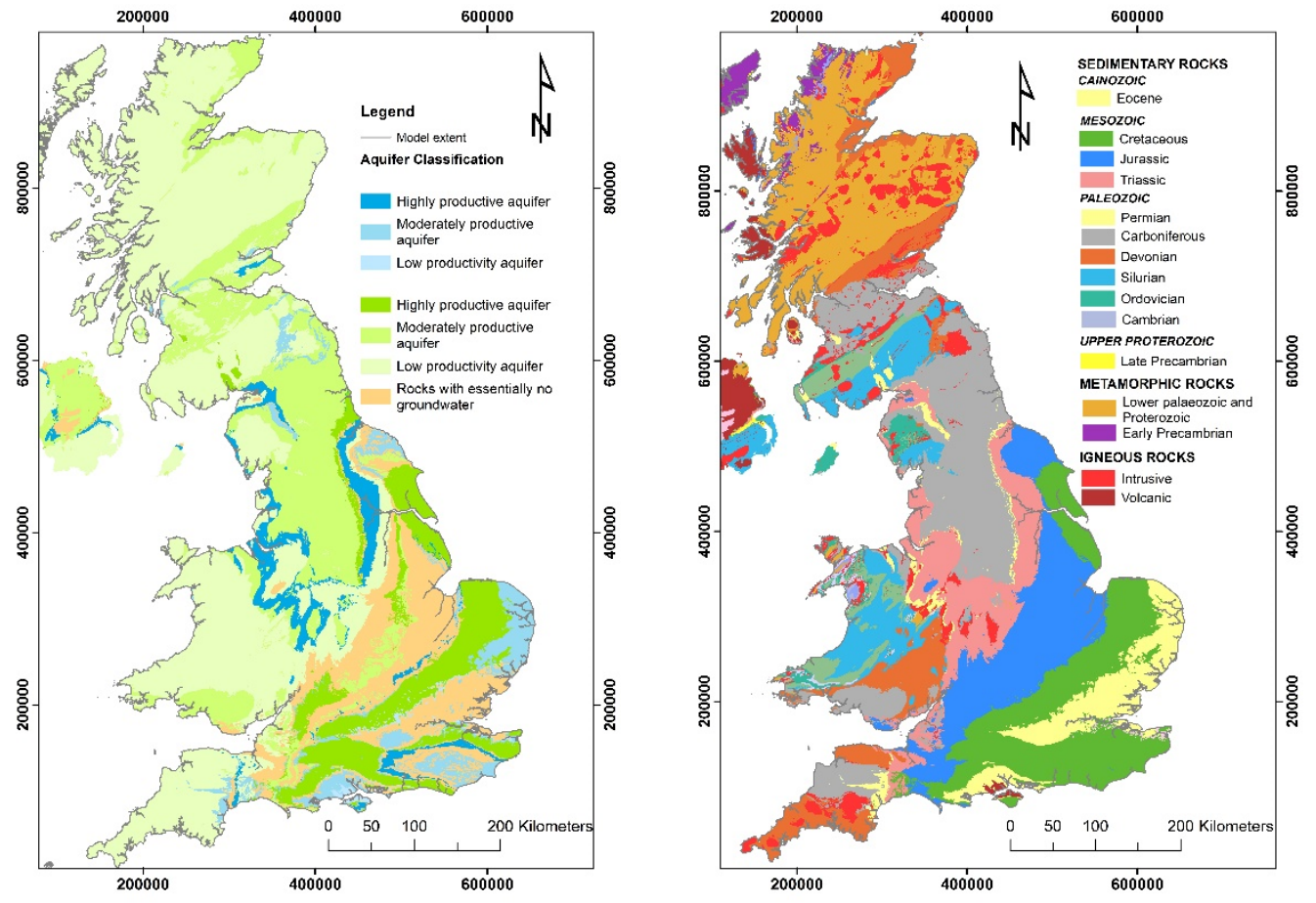

(a)

(b)

820

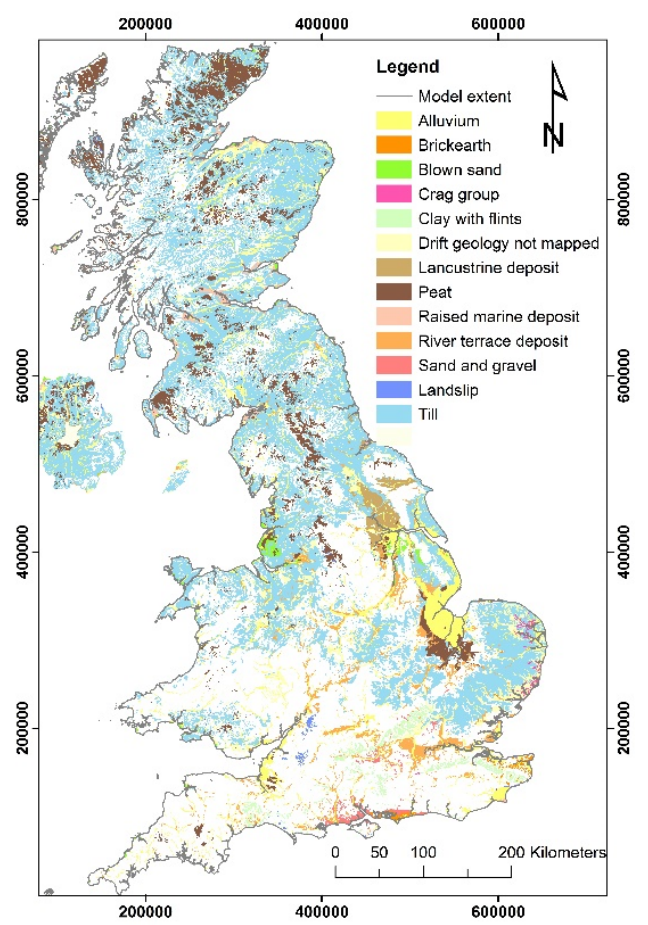

822 Figure 5. Geological maps of the UK. a) Hydrogeological map. b) Bedrock geology map. c) Superficial 

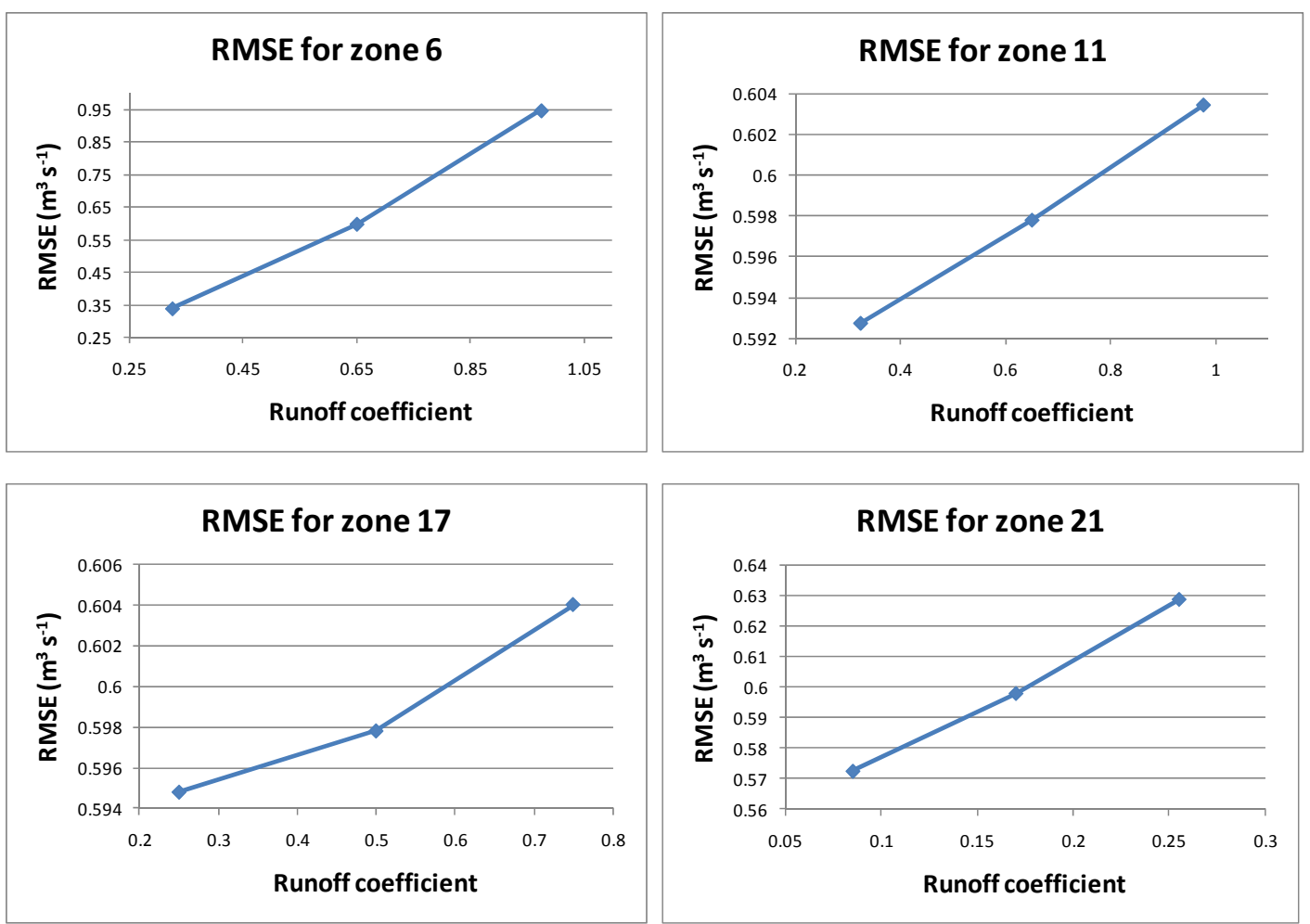

827

Figure 6. Plots of RMSE values from different runs against the runoff coefficient values at selected runoff zones

830

831

832

833

834

835

836

837

838

839

840

841

842 


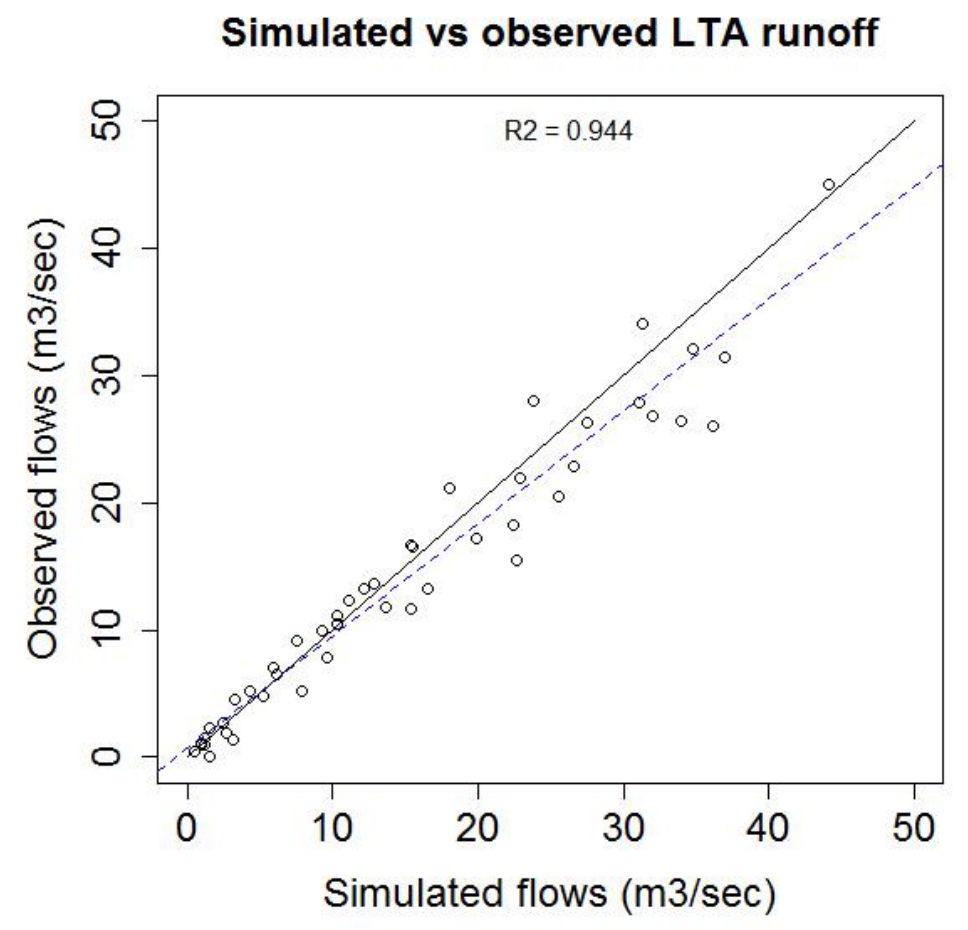

843

844 Figure 7 Comparison between the simulated and observed long term average runoff at the gauging 845 stations shown in Figure 1. Solid line represents the one to one match between the two datasets.

846 Dashed line is the trendline or the linear relationship between the two datasets.

847 

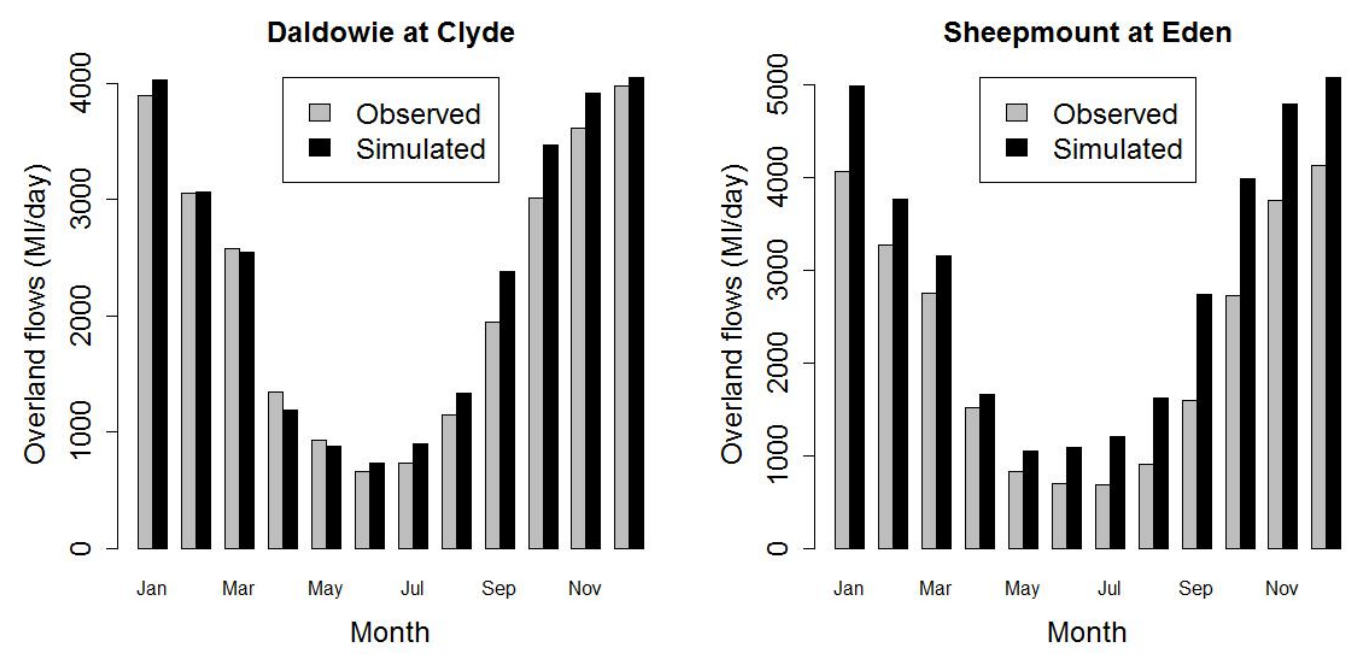

855
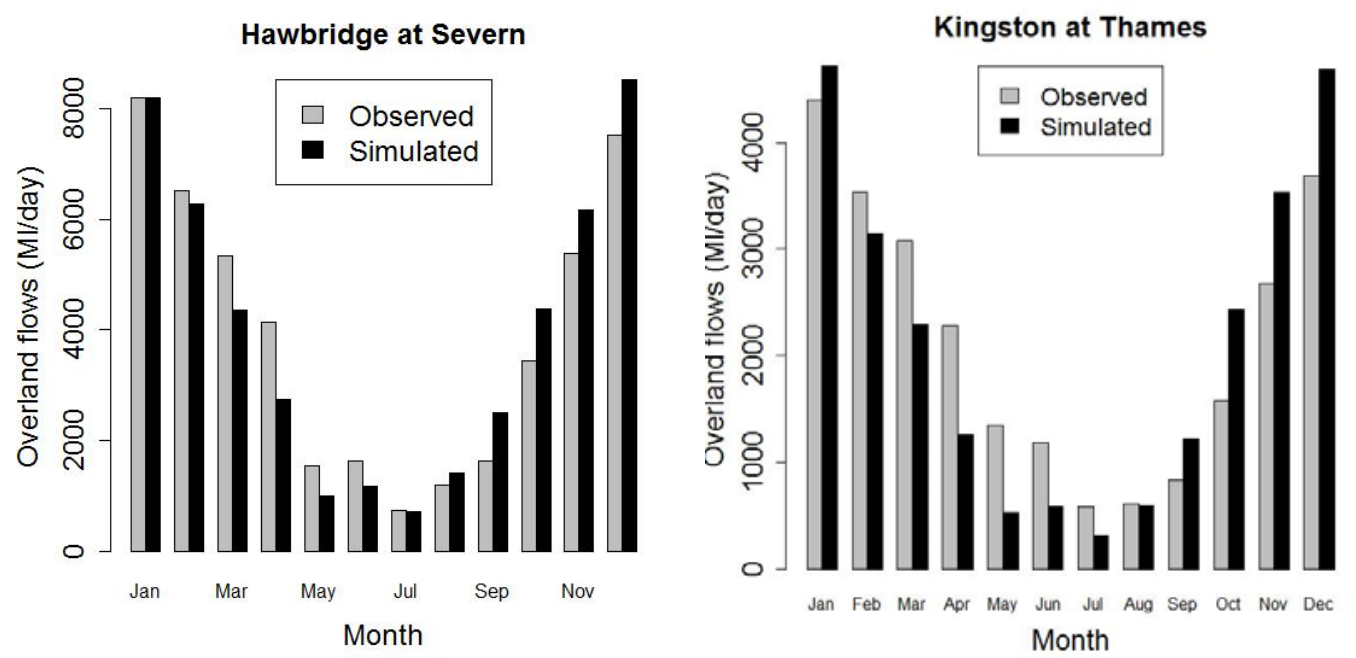

856

857

Figure 8 Comparison between the simulated and observed monthly average runoff at the gauging

858 stations represented by red circles shown in Figure 1

859

860

861

862

863

864 

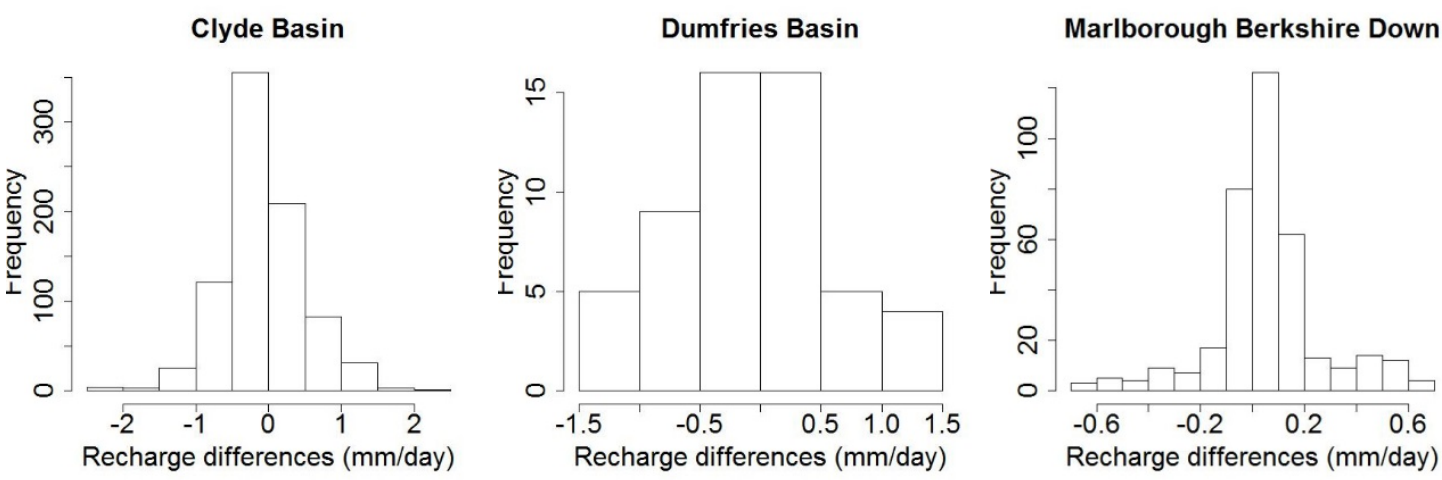

Figure 9 Histograms for the recharge differences between this national recharge estimates and those

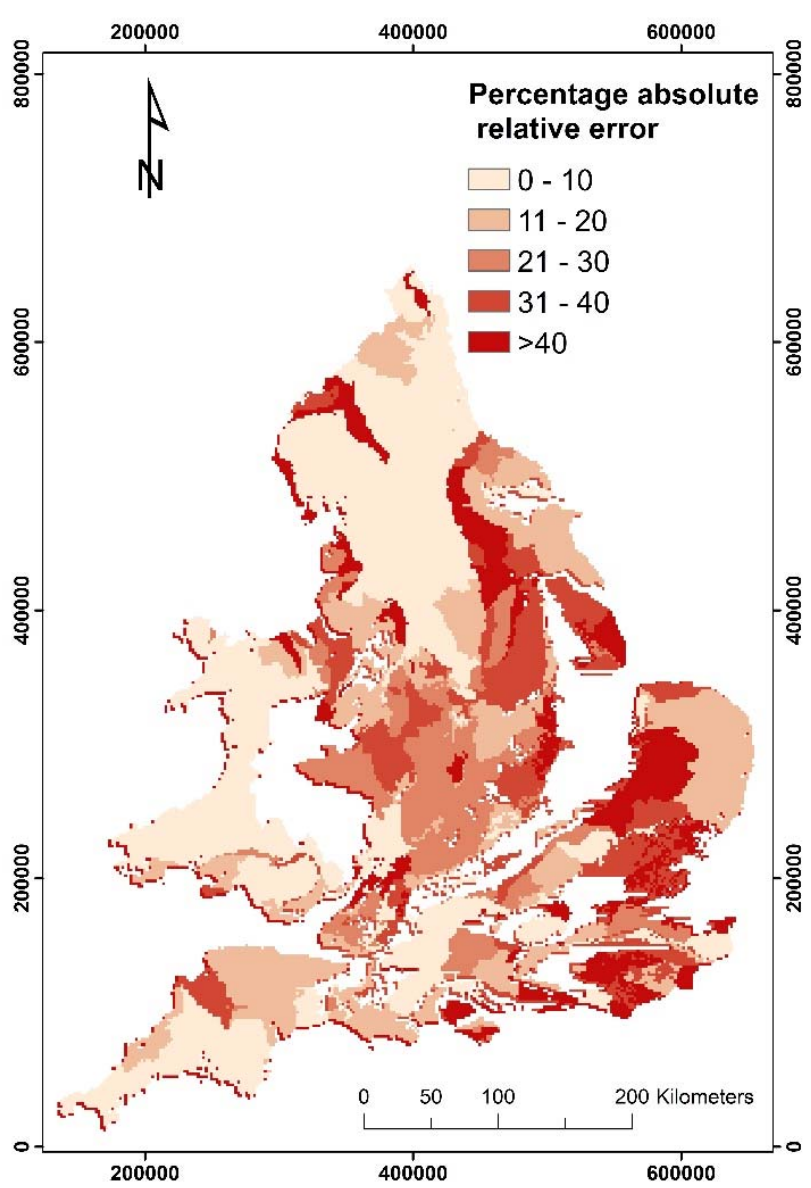

(a)

876

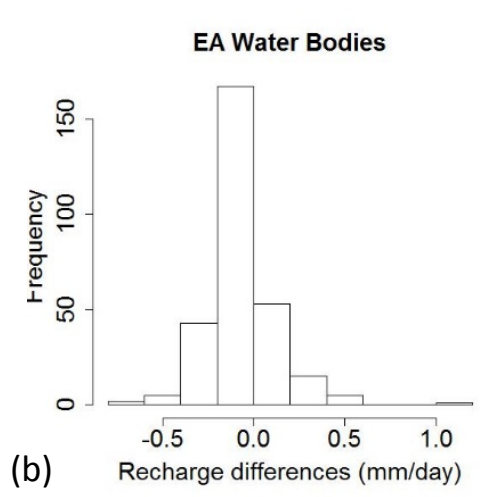

Simulated vs EA Estimated Recharge

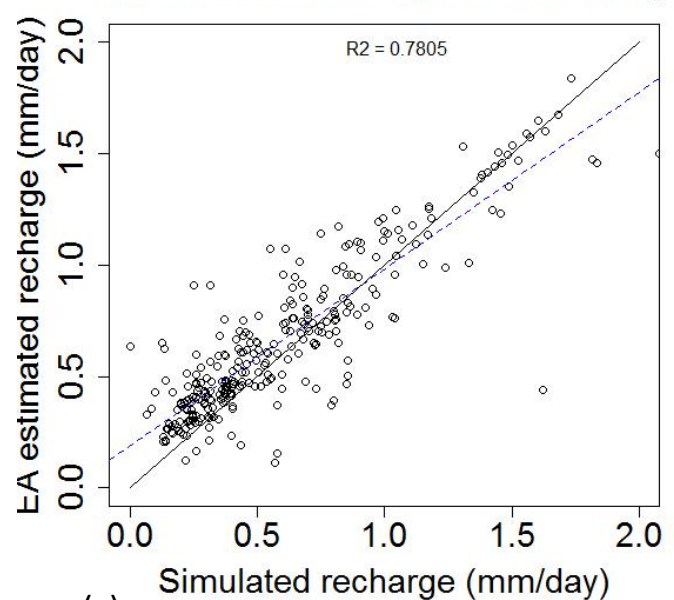

(c)

877 Figure 10 Comparison between ZOODRM-derived and EA estimated recharge values over

878 groundwater bodies. A) Percentage absolute relative error. B) histogram of recharge differences. C)

879 Scatter plot showing the match between the two datasets (Solid line represents the one to one

880 match between the two datasets. Dashed line is the trendline or the linear relationship between the

881 two datasets). Contains public sector information licensed under the Open Government Licence

882 v3.0 (http://www.nationalarchives.gov.uk/doc/open-government-licence/version/3/) 

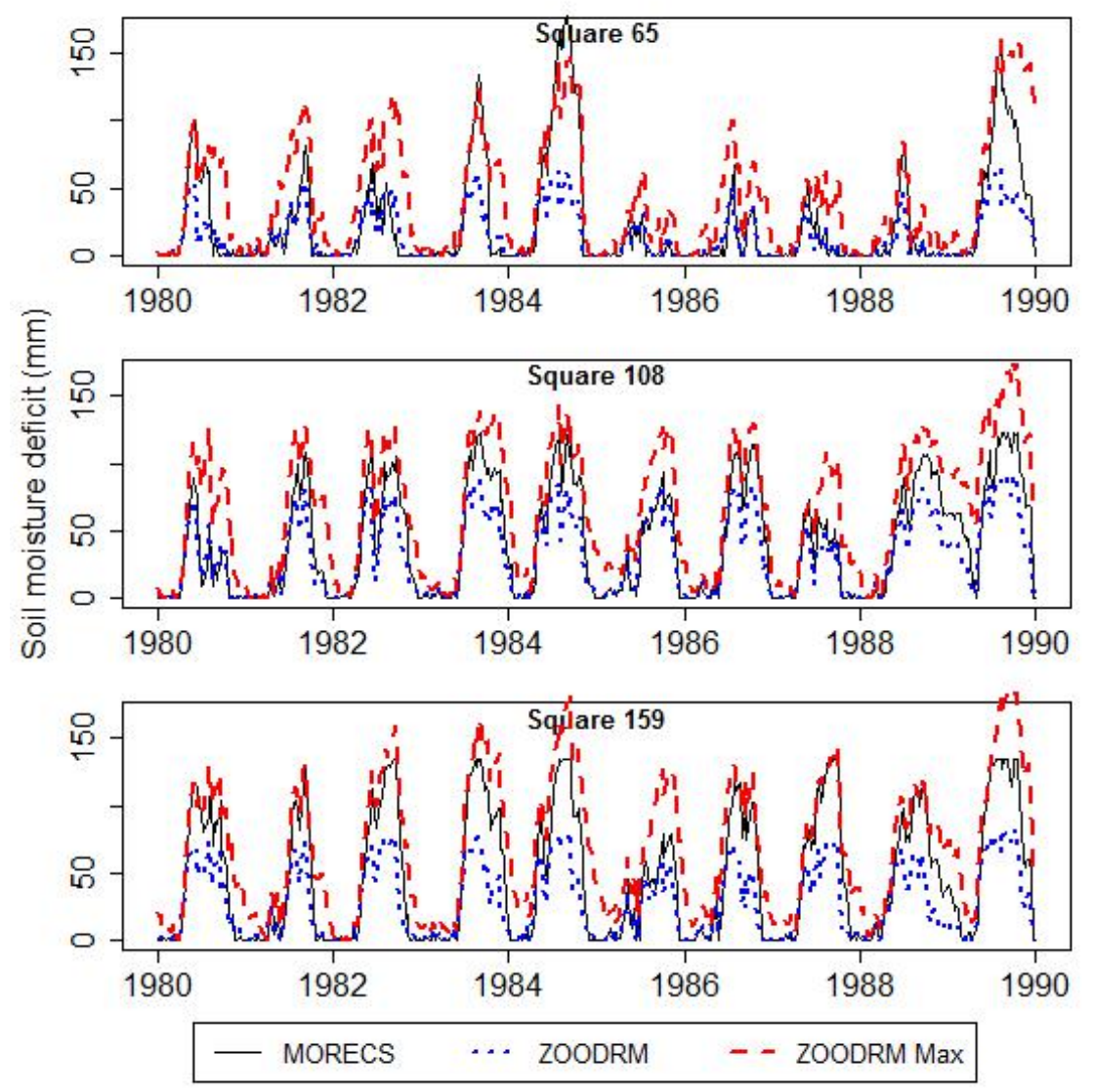

883

884 Figure 11 Comparison between soil moisture deficit changes with time as calculated by MORECS and 885 the recharge model (ZOODRM) used in this study

886

887

888

889

890

891

892

893

894

895

896

897 


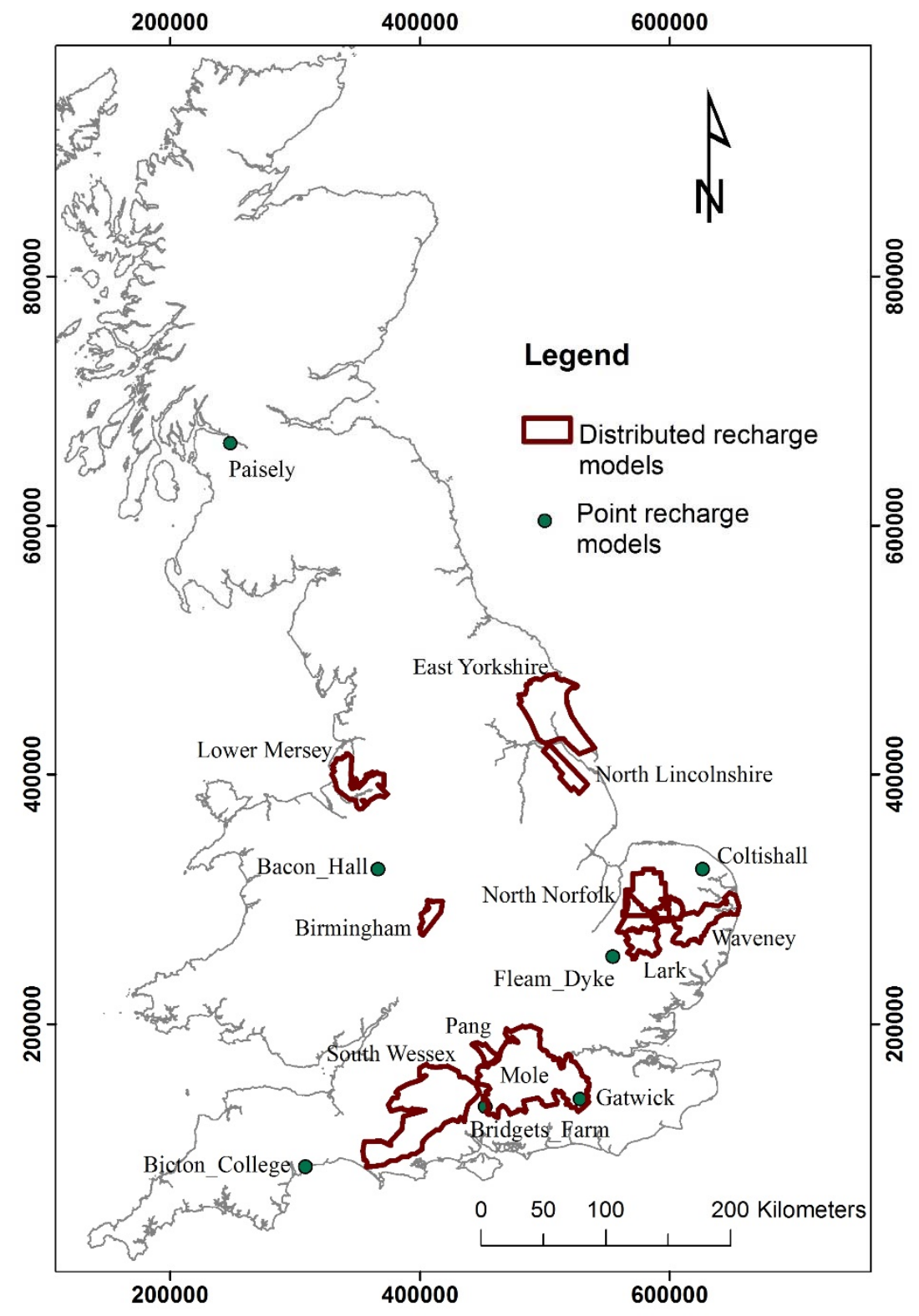

898

899 Figure 12 Distributed and point calculation benchmarking models. "Contains Ordnance Survey data $\odot$ 900 Crown Copyright and database rights 2014"

901

902

903

904

905

906

907 


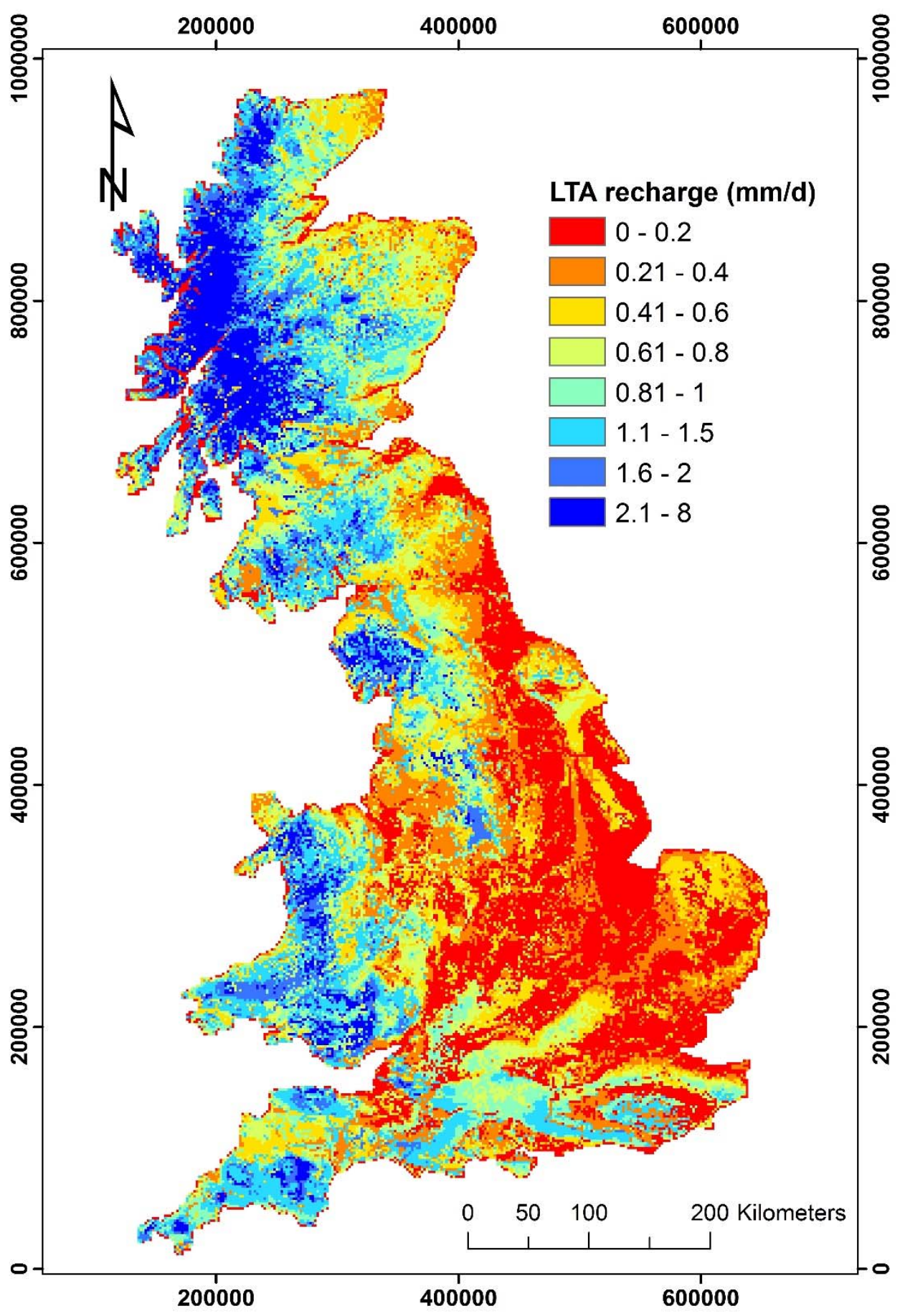

910 Figure 13. Long term average groundwater recharge for the UK between 1962 and 2001. 
Table 1 Summary of weather characteristics in England, Scotland, and Wales.

\begin{tabular}{|l|l|l|l|}
\hline & England & Scotland & Wales \\
\hline $\begin{array}{l}\text { Maximum } \\
\text { temperature }\left({ }^{\circ} \mathrm{C}\right)\end{array}$ & 20.6 & 16.9 & 19.1 \\
\hline $\begin{array}{l}\text { Month of } \\
\text { maximum } \\
\text { temperature }\end{array}$ & July & July & July \\
\hline $\begin{array}{l}\text { Minimum } \\
\text { temperature }\left({ }^{\circ} \mathrm{C}\right)\end{array}$ & 1.0 & -0.2 & 1.1 \\
\hline $\begin{array}{l}\text { Month of } \\
\text { minimum } \\
\text { temperature }\end{array}$ & February & January & February \\
\hline $\begin{array}{l}\text { Average rainfall } \\
\text { (mm year }{ }^{-1} \text { ) }\end{array}$ & 840 & 1520 & 1435 \\
\hline & & & \\
\hline
\end{tabular}

Table 2 Maximum root depth and depletion factor of the crop types specified at the grid nodes

\begin{tabular}{|l|l|l|}
\hline Landuse type & Maximum root depth $(\mathrm{m})$ & Crop depletion factor \\
\hline Broad-leaved/mixed woodland & 2 & 0.8 \\
\hline Coniferous woodland & 1.5 & 0.7 \\
\hline Arable and horticulture & 0.75 & 0.8 \\
\hline Grassland & 0.45 & 0.5 \\
\hline Semi-natural grass & 0.45 & 0.5 \\
\hline Mountain, heath, and bog & 0.12 & 0.37 \\
\hline Built up areas & 0.9 & 0.5 \\
\hline
\end{tabular}

922 Table 3 Mean observed flows and runoff flows estimated using the base flow indices for the four 923 catchment areas upstream the gauging stations shown by red circles in Figure 1.

\begin{tabular}{|l|l|l|l|l|l|}
\hline Catchment & $\begin{array}{l}\text { Area } \\
\left.\mathrm{km}^{2}\right)\end{array}$ & $\begin{array}{l}\text { Rainfall } \\
(\mathrm{mm} \\
\left.\mathrm{day}^{-1}\right)\end{array}$ & $\begin{array}{l}\text { Mean flow provided } \\
\text { by the hydrometric } \\
\text { register }\left(\mathrm{m}^{3} / \mathrm{sec}\right)\end{array}$ & $\begin{array}{l}\text { Base flow } \\
\text { index }\end{array}$ & $\begin{array}{l}\text { Runoff } \\
\left(\mathrm{m}^{3} / \mathrm{sec}\right) /(\mathrm{Ml} \text { day } \\
1)\end{array}$ \\
\hline $\begin{array}{l}\text { Clyde upstream } \\
\text { Daldowie }\end{array}$ & 1903 & 3.12 & 48.68 & 0.46 & $26.29 / 2271$ \\
\hline $\begin{array}{l}\text { Eden upstream } \\
\text { Sheepmount }\end{array}$ & 2286.5 & 3.17 & 51.9 & 0.49 & $26.47 / 2287$ \\
\hline $\begin{array}{l}\text { Severn } \\
\text { upstream } \\
\text { Hawbridge }\end{array}$ & 9895 & 2.18 & 107.1 & 0.58 & $44.98 / 3886$ \\
\hline $\begin{array}{l}\text { Thames } \\
\text { upstream } \\
\text { Kingston }\end{array}$ & 9948 & 1.97 & 77.87 & 0.64 & $28.03 / 2422$ \\
\hline
\end{tabular}


Table 4 Water balance simulated from 1962 to 2002 for the four catchment areas upstream the gauging stations shown by red circles in Figure 1.

\begin{tabular}{|l|l|l|l|l|l|l|}
\hline Catchment & $\begin{array}{l}\text { Area } \\
\left.\mathrm{km}^{2}\right)\end{array}$ & $\begin{array}{l}\text { Rainfall } \\
(\mathrm{mm} \\
\left.\mathrm{day}^{-1}\right)\end{array}$ & $\begin{array}{l}\text { Evapo- } \\
\text { transpiration }_{\left(\mathrm{mm} \mathrm{day}^{-1}\right)}\end{array}$ & $\begin{array}{l}\text { Runoff } \\
\left(\mathrm{mm} \mathrm{day}^{-1} / \mathrm{Ml}\right. \\
\left.\mathrm{day}^{-1}\right)\end{array}$ & $\begin{array}{l}\text { Change } \\
\text { in soil } \\
\text { storage } \\
(\mathrm{mm} \text { day } \\
1\end{array}$ & $\begin{array}{l}\text { Recharge } \\
(\mathrm{mm} \text { day } \\
1\end{array}$ \\
\hline $\begin{array}{l}\text { Clyde upstream } \\
\text { Daldowie }\end{array}$ & 1903.1 & 3.12 & 1.083 & $1.17 / 2226$ & 0.017 & 0.85 \\
\hline $\begin{array}{l}\text { Eden upstream } \\
\text { Sheepmount }\end{array}$ & 2286.5 & 3.17 & 1.07 & $1.19 / 2720$ & 0.017 & 0.89 \\
\hline $\begin{array}{l}\text { Severn } \\
\text { upstream } \\
\text { Hawbridge }\end{array}$ & 9895 & 2.18 & 1.22 & $0.44 / 4350$ & 0.004 & 0.51 \\
\hline $\begin{array}{l}\text { Thames } \\
\text { upstream } \\
\text { Kingston }\end{array}$ & 9948 & 1.97 & 1.28 & $0.21 / 2090$ & 0.006 & 0.47 \\
\hline
\end{tabular}

Table 5 Comparison between the simulated recharge and that reported in the literature and obtained from the Environment Agency. For model locations, refer to Figure 12.

\begin{tabular}{|c|c|c|c|c|}
\hline $\begin{array}{l}\text { Model / } \\
\text { (simulation } \\
\text { date) }\end{array}$ & $\begin{array}{l}\text { Simulated } \\
\text { recharge or } \\
\text { total flow } \\
(\mathrm{mm} / \mathrm{a})\end{array}$ & $\begin{array}{l}\text { Literature } \\
\text { recharge or } \\
\text { hydrological } \\
\text { excess water } \\
(\mathrm{mm} / \mathrm{a})\end{array}$ & $\begin{array}{l}\text { Percentage } \\
\text { difference } \\
\text { and } \\
\text { qualitative } \\
\text { assessment }\end{array}$ & Notes \\
\hline $\begin{array}{l}\text { North } \\
\text { Norfolk } \\
(1980- \\
1990)\end{array}$ & 126 & 125 & $\begin{array}{l}0.8 \\
\text { (Very good) }\end{array}$ & $\begin{array}{l}\text { Distributed recharge (Yusof et } \\
\text { al., 2002). }\end{array}$ \\
\hline $\begin{array}{l}\text { Pang } \\
(1992- \\
1995)\end{array}$ & 237 & $\begin{array}{l}235 \\
\text { (MORECS) } \\
299 \text { (TCM) } \\
313 \\
\text { (ANSWERS) } \\
343 \text { (RLM) }\end{array}$ & $\begin{array}{l}1 \text { to } 30 \\
\text { (Very good } \\
\text { to poor) }\end{array}$ & $\begin{array}{l}\text { Distributed recharge (Bradford } \\
\text { et al., 2002). }\end{array}$ \\
\hline $\begin{array}{l}\text { South } \\
\text { Wessex }\end{array}$ & 346 & 355 & 2.5 (Good) & $\begin{array}{l}\text { Distributed recharge } \\
\text { (Whiteman et al., 2012). }\end{array}$ \\
\hline $\begin{array}{l}\text { North } \\
\text { Lincolnshire } \\
\text { (1961 - } \\
1997)\end{array}$ & 175 & 213 & $\begin{array}{l}18 \\
\text { (Adequate) }\end{array}$ & $\begin{array}{l}\text { Distributed recharge } \\
\text { (Hutchinson et al., 2012). }\end{array}$ \\
\hline $\begin{array}{l}\text { Waveney } \\
(1970- \\
2009)\end{array}$ & 66 (99) & 102 & $\begin{array}{l}35(0.03) \\
\text { Poor (Very } \\
\text { good) }\end{array}$ & $\begin{array}{l}\text { Distributed recharge (Black et } \\
\text { al., 2012): values in bracket } \\
\text { are obtained after changing } \\
\text { the runoff coefficient value of } \\
\text { one runoff zone. }\end{array}$ \\
\hline
\end{tabular}




\begin{tabular}{|c|c|c|c|c|}
\hline $\begin{array}{l}\text { Lark } \\
(1970- \\
2009)\end{array}$ & 91 & 147 & 38 (Poor) & $\begin{array}{l}\text { Distributed recharge (Black et } \\
\text { al., 2012). }\end{array}$ \\
\hline $\begin{array}{l}\text { Lower Little } \\
\text { Ouse (1970- } \\
\text { 2003) }\end{array}$ & 91 & 115 & 21 (Poor) & $\begin{array}{l}\text { Distributed recharge } \\
\text { (Environment Agency, 2008b): } \\
\text { Literature recharge estimated } \\
\text { from report figure. }\end{array}$ \\
\hline $\begin{array}{l}\text { Ely Ouse } \\
(1970- \\
2003)\end{array}$ & 128 & 146 & $\begin{array}{l}12 \\
\text { (Adequate) }\end{array}$ & $\begin{array}{l}\text { Distributed recharge } \\
\text { (Environment Agency, 2008a): } \\
\text { Literature recharge estimated } \\
\text { from report figure. }\end{array}$ \\
\hline $\begin{array}{l}\text { Lower } \\
\text { Mersey Basin } \\
(2004)\end{array}$ & 181 & 277 & 34 (Poor) & $\begin{array}{l}\text { Distributed recharge (ESI, } \\
\text { 2009): Literature recharge } \\
\text { calculated over nodes with no } \\
\text { impermeable surfaces. }\end{array}$ \\
\hline $\begin{array}{l}\text { Mole (1970 - } \\
\text { 2006) }\end{array}$ & 188 & 165 & $\begin{array}{l}14 \\
\text { (Adequate) }\end{array}$ & $\begin{array}{l}\text { Distributed recharge } \\
\text { (Environment Agency, 2008c). }\end{array}$ \\
\hline Birmingham & 194 & 129 & $\begin{array}{l}50 \text { (Very } \\
\text { poor) }\end{array}$ & $\begin{array}{l}\text { Distributed recharge (ESI, } \\
\text { 2014): Literature recharge } \\
\text { estimated from report figure. }\end{array}$ \\
\hline $\begin{array}{l}\text { East } \\
\text { Yoykshire }\end{array}$ & 160 & 159 & $\begin{array}{l}0.6 \text { (Very } \\
\text { good) }\end{array}$ & $\begin{array}{l}\text { Distributed recharge (ESI, } \\
\text { 2015): Literature recharge } \\
\text { estimated from report figure. }\end{array}$ \\
\hline $\begin{array}{l}\text { Coltishall } \\
(1961- \\
1990)\end{array}$ & 145 & 111 & 30 (Poor) & $\begin{array}{l}\text { Point data: Potential recharge } \\
\text { or hydrological excess water } \\
\text { (Herrera-Pantoja and Hiscock, } \\
\text { 2007) compared to the sum of } \\
\text { recharge and runoff simulated } \\
\text { in this study. }\end{array}$ \\
\hline $\begin{array}{l}\text { Gatwick } \\
(1961-1990\end{array}$ & 379 & 246 & $\begin{array}{l}54 \\
\text { (Very poor) }\end{array}$ & $\begin{array}{l}\text { Point data: Potential recharge } \\
\text { or hydrological excess water } \\
\text { (Herrera-Pantoja and Hiscock, } \\
\text { 2007) compared to the sum of } \\
\text { recharge and runoff simulated } \\
\text { in this study. }\end{array}$ \\
\hline $\begin{array}{l}\text { Paisely } \\
(1961- \\
1990)\end{array}$ & 578 & 617 & 6.3 (Good) & $\begin{array}{l}\text { Point data: Potential recharge } \\
\text { or hydrological excess water } \\
\text { (Herrera-Pantoja and Hiscock, } \\
\text { 2007) compared to the sum of } \\
\text { recharge and runoff simulated } \\
\text { in this study. }\end{array}$ \\
\hline $\begin{array}{l}\text { Bridgets } \\
\text { Farm } \\
(1976- \\
1980)\end{array}$ & 325 & 356 & 8.7 (Good) & $\begin{array}{l}\text { Point data: Recharge values } \\
\text { from the FRLM model } \\
\text { reported by Ragab et al. } \\
\text { (1997). Model uses grass as } \\
\text { landuse. } \\
\text { Landuse specified at the } \\
\text { ZOODRM model cell are: } 40 \% \\
\text { Arable, } 49 \% \text { Grass, } 11 \% \text { Urban }\end{array}$ \\
\hline
\end{tabular}




\begin{tabular}{|c|c|c|c|c|}
\hline $\begin{array}{l}\text { Fleam Dyke } \\
(1978- \\
1982)\end{array}$ & 140 & 251 & 44.2 (Poor) & $\begin{array}{l}\text { Point data: Recharge values } \\
\text { the FRLM model reported by } \\
\text { Ragab et al. (1997). Model } \\
\text { uses grass as landuse. } \\
\text { Landuse specified at the } \\
\text { ZOODRM model cell are: } 88 \% \\
\text { Arable, } 0.7 \% \text { Grass, } 7.2 \% \\
\text { Mountains/Bog }\end{array}$ \\
\hline $\begin{array}{l}\text { Bicton } \\
\text { College } \\
(1988- \\
1992)\end{array}$ & 222 & 290 & 23.4 (Poor) & $\begin{array}{l}\text { Point data: Recharge values } \\
\text { the FRLM model reported by } \\
\text { Ragab et al. (1997). Model } \\
\text { uses grass as landuse. } \\
\text { Landuse specified at the } \\
\text { ZOODRM model cell are: } 46 \% \\
\text { Arable, } 23 \% \text { Grass, } 25 \% \text { Urbar }\end{array}$ \\
\hline $\begin{array}{l}\text { Bacon Hall } \\
(1987 \text { - } \\
1991)\end{array}$ & 148 & 263 & 43.7 (Poor) & $\begin{array}{l}\text { Point data: Recharge values } \\
\text { the FRLM model reported by } \\
\text { Ragab et al. (1997). Model } \\
\text { uses grass as landuse. } \\
\text { Landuse specified at the } \\
\text { ZOODRM model cell are: } 14 \% \\
\text { Mixed woodland, } 57 \% \text { Arable, } \\
28 \% \text { Grass }\end{array}$ \\
\hline
\end{tabular}

931 